\title{
A UNIFIED TREATMENT OF FINANCE LESSEES' REVOCATION OF AGCEPTANCE UNDER THE UNIFORM COMMERGIAL CODE
}

\author{
MichaEL I. TSAI $\dagger$
}

\section{INTRODUCTION}

It is a common ${ }^{1}$ practice in certain business and consumer contexts to make use of three-way acquisitive transactions called "finance leases." The basic finance lease arises when a party, the "finance lessee," wishes to acquire goods. The finance lessee engages a financing party, the "finance lessor," to assist it. Pursuant to its agreement with the finance lessee, the finance lessor buys the goods from a "supplier," a seller selected by the finance lessee, and in turn "leases"3 the goods to the finance lessee.

† A.B. 1983, Harvard University; M.A. 1986, University of California at San Diego; J.D. Candidate 1989, University of Pennsylvania.

1 The United States Department of Commerce forecasted for 1988 that leasing would account for $\$ 99.8$ billion of the $\$ 328.8$ billion spent by businesses on equipment. See U.S. DeP'T OF CoMmerce, U.S. INDUSTRIAL OUTLOOK 1988, at 57-1. The proportion of equipment leasing to total business investment in equipment has grown yearly from $12.5 \%$ in 1978 to a predicted $30.4 \%$ for 1988 . See id. at $57-1$, -4. Since 1978, equipment leasing has grown twice as fast as total business investment in equipment, and it was expected to grow $10.2 \%$ from 1987 to 1988. See id. at 57-1; see also U.S. Dep't of Commerce, A Competitive Assessment of the United States EQUIPMENT LEASING INDUSTRY 4 (1985) (making similar estimates for the years 1978 to 1983). Three-party transactions are a common form of leasing arrangement. See Boss, Panacea or Nightmare? Leases in Article 2, 64 B.U.L. REv. 39, 42, 57-58 (1984).

${ }^{2}$ This term is susceptible to different definitions. See Reisman \& Mooney, Drafting, Negotiating, and Construing the Equipment Lease-An Overview, in EQUIPMENT Leasing-Leveraged Leasing 1, 29 \& n.90 (B. Fritch \& A. Reisman eds. 1980) [hereinafter Leveraged Leasing]. As used in this Comment, the term "finance lease" will refer to the set of transactions described in the accompanying paragraph in the text. This usage should be compared with the definition in U.C.C. $\$ 2 \mathrm{~A}-103(1)(\mathrm{g})$, which is based on the functions of the parties and thereby encompasses the sale-andleaseback situation. See infra note 62 and accompanying text; see also U.C.C. § 2A$103(\mathrm{~g})$ official comment (explaining application of the definition to sale-and-leaseback transactions); infra notes 149-61 (discussing the definitions pertinent to finance leases). Finance leases can be more complex than the basic situation described here and involve more than three parties. See Shrank, Leveraged Leasing, in BASICS of EQUIPMENT LEASING 1987, at 327-32 (R. Bayer \& I. Shrank co-chairmen); Fritch \& Shrank, Leveraged Leasing, in LEVERAGed LeAsING, supra, at 211, 218-23. This Comment will, however, focus on the three principal parties.

s Although the parties term this element of the transaction a "lease," whether it is in fact a lease is a complex matter. See infra notes 25-37 and accompanying text. 
There are many ways to structure a finance lease. Depending on the particular provisions of the agreements between the various parties, the transaction between the finance lessor and the finance lessee may be viewed under the Uniform Commercial Code ("UGG" or the "Code") as either a "true" lease or as part of a transaction that creates a security interest ("security interest lease"). This distinction is important because a transaction involving a purported lease that creates a security interest is treated under the Code as providing for a sale and the taking of a security interest. ${ }^{5}$ A true lease, on the other hand, is treated simply as a lease. ${ }^{\boldsymbol{B}}$ Hence, if a purported lease actually involves a security transaction, the sales aspects of the transaction will be governed by Article 2 (Sales) of the UCG, while the security aspects will be governed by Article 9 (Secured Transactions). If a purported lease is a true lease, however, it will be within the scope of the recently promulgated Article 2A (Leases). ${ }^{7}$ Because some of the provisions in these articles differ significantly, this distinction will affect the rights of all the parties to the transaction. ${ }^{8}$

The differences between the operation of Articles 2 and 9 and Article $2 \mathrm{~A}$ are especially marked in the case of finance leases. Although Article 2A generally follows Article $2,{ }^{9}$ it also contains special rules for true leases that are finance leases ("true finance leases"). Article 2A recognizes that the issues underlying three-party finance leases are different from those implicated in ordinary two-party leases, and so it deals explicitly with true finance leases. ${ }^{10}$ By contrast, neither Article 2 nor Article 9 provides any explicit treatment for security interest leases that are finance leases ("security interest finance leases"); as a result, those special rules that exist have been judicially created on an ad hoc basis. ${ }^{11}$

4 See U.C.C. § 1-201(37); infra notes 25-37 and accompanying text.

- See infra notes 48-63 and accompanying text.

'See U.C.C. § 2A-102 ("This Article applies to any transaction, regardless of form, that creates a lease.").

7 Article $2 \mathrm{~A}$ is a recent addition to the UCC. Associated with it are conforming amendments to $\S \S 1-105,1-201(37)$, and 9-113. The new article and conforming amendments were adopted in 1987 by the American Law Institute and National Conference of Commissioners of Uniform State Laws and have been introduced or enacted in fourteen states as of August 1988. See Miller \& Rohner, Introduction to the Uniform Commercial Code Annual Survey, 43 Bus. LAw. 1255, 1256 n.5 (1988); see also Bayer, Personal Property Leasing: Article $2 A$ of the Uniform Commercial Code, 43 Bus. LAw. 1491, 1493 \& n.16 (1988) (noting that Oklahoma has enacted Article 2A). This Comment uses the text reproduced in 1A U.L.A. 417-97 (Supp. 1988).

${ }^{8}$ See infra note 22.

- See U.C.C. § 2A-101 official comment.

10 See infra notes 149-61 and accompanying text.

11 See Mooney, Personal Property Leasing: A Challenge, 36 Bus. LAw. 1605, 1618-21 (1981) (discussing attempts by courts to fashion rules to deal with finance 
This Comment examines one area in which finance leases that are true leases and those that are security interest leases are treated differently: the remedy of revocation of acceptance. Revocation of acceptance is a goods-oriented remedy that allows a buyer or lessee, in appropriate circumstances, to return previously accepted goods to the seller or lessor and recover any payments already made. ${ }^{12}$ In an ordinary two-party sale or lease, it involves the right of a buyer or lessee to terminate the contract and recover damages when the goods received are sufficiently nonconforming. ${ }^{13}$ In the three-party setting of the finance lease, revocation is more complicated. Additional issues arise, including whether the finance lessee may seek this remedy against the supplier or the finance lessor, or both, and whether the finance lessor may revoke against the supplier. ${ }^{14}$ These questions become particularly important when the supplier is unable or unwilling to perform on its obligations or pay damages, for then the answer to whether the finance lessee has a right of revocation against the finance lessor will determine which of the two bears any loss resulting from the nonconforming goods. ${ }^{15}$ Under Articles 2 and 2A, revocation of acceptance is expressly available to ordinary buyers, to ordinary lessees under true leases, and, in limited instances, to finance lessees under true finance leases. ${ }^{16}$ However, according to the one reported case to decide this issue generally, General Electric Credit Corp. v. Ger-Beck Machine Co. ("GECC'), ${ }^{17}$ revocation of acceptance is not available to finance lessees under security interest finance leases. ${ }^{18}$

In Part I, this Comment examines the distinction drawn in the Code between true leases and security interest leases and the effect of this distinction on how three-party transactions are perceived under the Code. Part II discusses the considerations underlying the remedy of revocation of acceptance. Part III compares Article 2A's treatment of revocation of acceptance in a true finance lease with the treatments advanced by the majority and dissent in GECC in the context of a security interest finance lease. The Comment argues that, at least with respect to revocation of acceptance, the policy concerns implicated in a security interest finance lease are the same as those implicated in a true finance lease. It then suggests that Article 2A's treatment of true finance leases

\footnotetext{
lease issues in pre-Article $2 \mathrm{~A}$ cases).

12 See infra notes 92-121 and accompanying text.

1s See infra notes 92-97 and accompanying text.

14 See infra notes 188-217 and accompanying text.

15 See infra notes $105-10$ \& 240-42 and accompanying text.

16 See infra notes $98-100$ \& $188-217$ and accompanying text.

17806 F.2d 1207 (3d Cir. 1986).

18 See infra notes 222-27 and accompanying text.
} 
successfully addresses these policy concerns and concludes that, despite GECC, the same treatment should be adopted by the courts in the context of security interest finance leases. ${ }^{19}$

\section{The True Lease Versus the Security Interest Lease}

Whether a transaction that the parties characterize as a lease is deemed $^{20}$ to be a lease or to create a security interest under the UCG determines whether it will be governed by the article on leases (Article $2 \mathrm{~A}$ ) or by the articles on sales (Article 2) and secured transactions (Article 9). ${ }^{21}$ This generally makes a great deal of difference not only to the parties involved, but to third parties as well. ${ }^{22}$ One particular difference lies in Article 2A's explicit treatment of finance leases, which

19 At this point, a note on terminology is required. In the pre-Article $2 \mathrm{~A}$ Code, there was no definition of "lease"; nevertheless, pre-amendment $\S 1-201(37)$ made it clear that a lease may or may not be "intended as security." Leases not intended as security are generally referred to as "true" leases. Leases that are intended as security are often called "security interest leases." Amended $\S 1-201$ (37) substituted "transaction [that] creates a security interest" for "lease intended as security," because the previous definition's "[ $r$ ]eference to the intent of the parties . . . has led to unfortunate results." U.C.C. $\$ 1-201$ (37) official comment. Furthermore, because the new definition of "lease" in \& 2A-103(1)(j) excludes the "retention or creation of a security interest," the notion of a "lease intended as security" has become a contradiction in terms. In an apparent drafting oversight, however, $\S 9-408$, which was not amended on the introduction of the new article, continues to use that term.

Unfortunately, the Article $2 \mathrm{~A}$ amendments, having recast the meaning of "lease," provide no alternative term for something that may be either a true lease or a security interest disguised as a lease when the nature of the transaction has not been resolved. See U.C.C. \$ 1-201(37) (providing that the nature of a lease should be "determined by the facts of each case"). "Purported lease" could serve such a function, along with the related terms "purported lessor" and "purported lessee." Because, however, unrestricted use of these terms would be cumbersome, this Comment will continue to use the pre-Article 2A terminology unless use of the adjective "purported" is necessary for clarity in the particular context. Note that amended $\$ 1-201(37)$ itself refers to "the lessee" in a transaction that creates a security interest.

To further simplify the terminology used in this Comment, lessees under security interest leases will be referred to as "security interest lessees," while lessees under true leases will be termed "true lessees." Lessees under security interest finance leases will be called "security interest finance lessees," and lessees under true finance leases will be "true finance lessees." Analogous terminology will be used for lessors.

${ }_{20}$ See infra notes 25-37 and accompanying text.

21 See infra notes 38-47 and accompanying text.

22 For example, a lessor must usually file a financing statement for a lease intended as security if it wishes to perfect its security interest and protect its rights in the leased property against other claimants. See U.C.C. \$ 9-302. Another important difference lies in the greater protection given to a lessee under a security interest lease after the lessee's default. The security interest lessee is given rights to redeem the leased property, see id. $\S 9-506$, and to claim any surplus from the lessor's disposition of the property, see id. $\S 9-504(2)$, while the true lessee is not, see id. $\S 2 \mathrm{~A}-527(5)$. This greater protection is given because a security interest lessee is considered to have an equity interest in the property, while a true lessee is not. See id. $\S 2 A-527(5)$ official comment. 
has no corresponding treatment in Articles 2 and 9. To fill this gap, some courts have attempted to parse transactions into their constituent elements. ${ }^{23}$ They recharacterize the structure of finance leases so that their components may be regarded as sales, leases, or security interests. This Part argues that recharacterizing a security interest finance lease ${ }^{24}$ into components recognizable under Articles 2 and/or 9 is not helpful, because doing so requires that courts make unwarranted generalizations regarding the substance and function of the transaction created by the parties. Such an approach is not as direct and accurate as focusing on the exact bargain between the parties.

\section{A. "Lease" or "Security Interest"?}

Under the UCG, "lease" and "security interest" are mutually exclusive terms. A lease is defined in section 2A-103(1)(j) as "a transfer of the right to possession and use of goods for a term in return for consideration, but a sale . . . or retention or creation of a security interest is not a lease."25 Whether a security interest has been created or retained in a transaction is therefore critical in classifying the transaction.

The test of " $[\mathrm{w}]$ hether a transaction creates a lease or security interest" is set out in considerable detail by amended section 1-201(37) ${ }^{28}$

23 See infra notes 48-63 and accompanying text.

24 For a discussion of the terminology used in this Comment, see supra note 19.

25 U.C.C. \& 2A-103(1)(j).

${ }^{26}$ Amended § 1-201(37) provides:

"Security interest" means an interest in personal property or fixtures which secures payment or performance of an obligation. . . .

Whether a transaction creates a lease or security interest is determined by the facts of each case; however, a transaction creates a security interest if the consideration the lessee is to pay the lessor for the right to possession and use of the goods is an obligation for the term of the lease not subject to termination by the lessee, and

(a) the original term of the lease is equal to or greater than the remaining economic life of the goods,

(b) the lessee is bound to renew the lease for the remaining economic life of the goods or is bound to become the owner of the goods,

(c) the lessee has an option to renew the lease for the remaining economic life of the goods for no additional consideration or nominal additional consideration upon compliance with the lease agreement, or

(d) the lessee has an option to become the owner of the goods for no additional consideration or nominal additional consideration upon compliance with the lease agreement.

A transaction does not create a security interest merely because it provides that

(a) the present value of the consideration the lessee is obligated to pay the lessor for the right to possession and use of the goods is substantially equal to or is greater than the fair market value of the goods at the time 
This revised section is the result of much discussion by courts and commentators as to what distinguishes true leases from leases intended as security. ${ }^{27}$ As now codified, the distinction is based on the economic realities of the transaction..$^{\mathbf{2 8}}$ The first two tests presented in the second

the lease is entered into,

(b) the lessee assumes risk of loss of the goods, or agrees to pay taxes, insurance, filing, recording, or registration fees, or service or maintenance costs with respect to the goods,

(c) the lessee has an option to renew the lease or to become the owner of the goods,

(d) the lessee has an option to renew the lease for a fixed rent that is equal to or greater than the reasonably predictable fair market rent for the use of the goods for the term of the renewal at the time the option is to be performed, or

(e) the lessee has an option to become the owner of the goods for a fixed price that is equal to or greater than the reasonably predictable fair market value of the goods at the time the option is to be performed.

For purposes of this subsection (37):

(x) Additional consideration is not nominal if (i) when the option to renew the lease is granted to the lessee the rent is stated to be the fair market rent for the use of the goods for the term of the renewal determined at the time the option is to be performed, or (ii) when the option to become the owner of the goods is granted to the lessee the price is stated to be the fair market value of the goods determined at the time the option is to be performed. Additional consideration is nominal if it is less than the lessee's reasonably predictable cost of performing under the lease agreement if the option is not exercised;

(y) "Reasonably predictable" and "remaining economic life of the goods" are to be determined with reference to the facts and circumstances at the time the transaction is entered into; and

(z) "Present value" means the amount as of a date certain of one or more sums payable in the future, discounted to the date certain. The discount is determined by the interest rate specified by the parties if the rate is not manifestly unreasonable at the time the transaction is entered into; otherwise, the discount is determined by a commercially reasonable rate that takes into account the facts and circumstances of each case at the time the transaction was entered into.

${ }^{27}$ See U.C.C. \$§ 1-201(37), 2A-103(1)(j) official comments; see also Coogan, Leases of Equipment and Some Other Unconventional Security Devices: An Analysis of UCC Section 1-201(37) and Article 9, 1973 DuKE L.J. 909, 954-73 (asserting that the standards contained in pre-amendment $\S 1-201(37)$ were inadequate for distinguishing a true lease from a secured transaction); Hawkland, The Impact of the Uniform Commercial Code on Equipment Leasing, 1972 U. ILL. L.F. 446, 450 ("The difference between a true lease and a security transaction lies in whether the lessee acquires an equity ownership through his rent payments."); Mooney, supra note 11, at 1610-15 (describing the "hodge-podge of subjective and extraneous criteria" used to distinguish true leases from security interests). For synopses of court opinions discussing the distinction between true leases and leases intended as security, see Mooney, True Lease or "Lease Intended as Security"-Treatment by the Courts, in 1C SECured Transactions Under the Uniform Commercial Code (MB) 2913 (1988).

${ }^{28}$ See U.C.C. § 1-201(37) official comment; see also Cooper, Identifying a Personal Property Lease Under the UCC, 49 OHIO ST. L.J. 195, 233-47 (1988) (agreeing with Article 2A's economic realities approach). 
paragraph of section 1-201(37) ${ }^{\mathbf{2 9}}$ determine whether a security interest is created by examining whether the lessee is obligated to become the effective owner of the goods. The second two tests in that paragraph ${ }^{30}$ focus on whether the lessee is compelled, in an economic sense, by the terms of the agreement to become the effective owner of the goods. In each of these situations, the economic realities facing the lessee are in practical terms identical to those of an owner of goods subject to a security interest. In all cases, the lessee continues to pay rent until it owns the goods, or until the goods are not worth anything to anyone else, and if the lessee does not pay, the lessor is empowered to repossess the goods.

The third paragraph of section 1-201(37) ${ }^{31}$ lists five factors that alone will not distinguish security interest leases from true leases. The first three clauses state that full payout leases, ${ }^{32}$ net leases, ${ }^{33}$ and leases with options to renew or buy ${ }^{34}$ are not necessarily security interest leases. The last two clauses specify that the same is true for leases with options for fair market value renewal ${ }^{35}$ or fair market value purchase. ${ }^{36}$ The final paragraph provides economic definitions of nominal consideration, remaining economic life, and present value. ${ }^{\mathbf{3 7}}$

\section{B. Scope of the Articles}

If a transaction is a true lease, it is subject to Article $2 \mathrm{~A} .^{38}$ If, however, a transaction is a purported lease that creates a security interest, Articles 2 and 9 govern. Article 9 is relevant because it applies to "any transaction (regardless of its form) which is intended to create a security interest." ${ }^{\text {"39 }}$ Article 2 also applies, because it governs "transac-

${ }^{29}$ See U.C.C. § 1-201(37)(first a) to (first b).

so See id. § 1-201(37)(first c) to (first d).

31 See id. § 1-201(37)(second a) to (e).

32 See id. § 1-201(37)(second a) (referring to leases in which the lessee is obligated to make payments over the term of the lease that equal or exceed the value of the leased goods).

${ }^{33}$ See id. § 1-201(37)(second b) (referring to leases in which the lessee is responsible for the incidental expenses associated with use or maintenance of the leased goods).

${ }^{34}$ See id. \$ 1-201(37)(second c).

35 See id. § 1-201(37)(second d).

${ }^{36}$ See id. $\S 1-201(37)(\mathrm{e})$.

${ }^{37}$ See id. $\S 1-201(37)(\mathrm{x})$ to $(\mathrm{z})$.

${ }^{38}$ See id. § 2A-102 ("This Article applies to any transaction, regardless of form, that creates a lease.").

${ }^{39} I d$. $\S 9-102(1)(a)$. There are some exceptions to this statement that are not important here. See id. $\S 9-104$. Article 9 also applies to sales of accounts or chattel paper, see id. $\S 9-102(1)(\mathrm{b})$, as illustrated in transactions $C$, see infra note 55 and accompanying text, and $C^{\prime}$, see infra text following note 62 . 
tions in goods." 40

Because a lease of goods is a "transaction in goods," there is a potential for a conflict in scope between Articles 2 and $2 \mathrm{~A} .{ }^{41}$ Of course, most of the provisions in Article 2 refer to a "buyer," a "seller," or a "sale." These terms are, however, not defined precisely enough to confine the scope of Article 2: "[a] 'sale' consists in the passing of title from the seller to the buyer for a price";42 " '[b]uyer' means a person who buys or contracts to buy goods";" and " 's] sells or contracts to sell goods."44

Undoubtedly, the drafters kept these terms vague to allow room for judicial interpretation. ${ }^{45}$ Indeed, many Article 2 provisions have been applied directly or through analogy to true leases. ${ }^{46}$ Now that the Code contains an article that deals explicitly with true leases, however, courts no longer need to expand the scope of Article 2 to encompass them. To the contrary, as this Comment argues, courts should instead expand the scope of Article 2A, at least in the context of finance leases and revocation of acceptance. ${ }^{47}$

\section{G. Recharacterization}

To illustrate the scope of Articles 2 and 2A, consider the case of a simple two-party leasing agreement. If the transaction creates a true lease, then it is governed by Article $2 \mathrm{~A} .{ }^{48}$ On the other hand, if the purported lease in such a two-party transaction is a security interest lease, then the transaction is treated as a sale by the purported lessor to the purported lessee, with a retention of a purchase money security interest $^{49}$ in the goods by the lessor. In such a case, the sales aspect of

40 "Unless the context otherwise requires, this Article applies to transactions in goods; it does not apply to any transaction which although in the form of . . . [a] sale is intended to operate only as a security transaction." Id. § $2-102$ (emphasis added). Because a security interest lease involves, in addition to the creation of a security interest in the leased goods, the transfer of ownership in the goods, the restriction in $\S 2-102$ does not apply. See infra notes 48-51, 224-27 \& 233-35 and accompanying text.

11 See, e.g., J.L. Teel Co. v. Houston United Sales, Inc., 491 So. 2d 851, 855 (Miss. 1986) ("An equipment lease is certainly a 'transaction in goods'." [sic] (quoting Miss. Code AnN. § 75-2-102 (1972))); cf. May Co. v. Trusnik, 54 Ohio App. 2d 71, 73,375 N.E.2d 72, 74 (1977) ("A 'transaction' as it is used in U.C.C. 2-102 encompasses a far wider activity than a 'sale." (citation omitted)).

42 U.C.C. \& 2-106(1).

43 Id. $\S 2-103(1)(\mathrm{a})$.

44 Id. $\S 2-103(1)(\mathrm{d})$.

to See id. § 1-103 (stating that case law applies unless particular provisions of the Code are to the contrary).

16 See infra note 104; infra notes 219-21 and accompanying text.

47 See infra notes 243-49 and accompanying text.

48 See supra notes 38-44 and accompanying text.

48 See U.C.C. $\S 9-107$ (defining as a purchase money security interest the extent 
the lease is governed by Article 2, while the security aspect of the lease is governed by Article 9. ${ }^{50}$ This is relatively straightforward because it is the only way to recharacterize such a two-party transaction. ${ }^{.1}$

In a three-party finance lease, however, there are three ways to recharacterize the transaction if it turns out to be a lease intended as security:

(A) "Lessor," as2 after buying the goods from "Supplier," sells the goods to "Lessee," financing that sale and taking a purchase money security interest in the goods; ${ }^{.53}$

(B) Lessee borrows funds from Lessor and purchases the goods from Supplier with the funds, at the same time giving Lessor a purchase money security interest in the goods. ${ }^{54}$

(C) Supplier sells the goods to Lessee, financing the sale and taking a purchase money security interest in the goods; then Supplier assigns or sells the security interest associated with the sale to Lessor. ${ }^{\text {ss }}$

These three characterizations present significantly different transactional structures that are treated differently under Articles 2 and 9. First, in variants $A$ and $B$, Lessee is deemed to give Lessor the security interest, while in $C$, Lessee is deemed to give it to Supplier. Thus,

to which the security interest secures either the purchase of the collateral or value given to enable the debtor to acquire rights in or use of the collateral).

${ }^{\text {so }}$ See supra notes $38-44$ and accompanying text.

s1 This is reflected in U.C.C. $\$ 9-206(2)$, which states: "When a seller retains a purchase money security interest in goods the Article on Sales (Article 2) governs the sale and any disclaimer, limitation or modification of the seller's warranties."

52 The parties are given labels in this Section to facilitate comparisons between the recharacterizations. The labels do not necessarily reflect the role of the parties in each case.

s3 See, e.g., General Electric Credit Corp. v. Ger-Beck Machine Co., 806 F.2d 1207, 1212 (3d Gir. 1986) (dissenting opinion) ("[T]he transaction between GECC [Lessor] and Ger-Beck [Lessee] was not merely a financing arrangement, but also a sale of equipment.").

54 See, e.g., id. at 1209 ("[P]laintiff [Lessor] provided nothing . . . except the money to finance Ger-Beck's [Lessee's] acquisition of the lathe from the supplier."); Miller Auto Leasing Co. v. Weinstein, 189 N.J. Super. 543, 547, 461 A.2d 174, 17677 (1983) ("Plaintiff [Lessor] provided nothing here except the . . . money ... to fund this sale . . . between $\mathrm{Z} \& \mathrm{~W}$ [Supplier] and defendants [Lessees]."); cf. Citicorp Leasing, Inc. v. Allied Institutional Distribs., Inc., 454 F. Supp. 511, 517 (W.D. Okla. 1977) ("[P]laintiff [Lessor] is not an assignee of commercial paper . . . .").

s5 See, e.g., Funding Sys. Leasing Corp. v. King Louie Int'l, Inc., 597 S.W.2d 624, 639 (Mo. Ct. App. 1979) (dissenting opinion) ("The full evidence proves ... . a straightforward, consummated two-party equipment lease-purchase between KingLouie [Lessee] and IGM [Supplier] which Funding Systems [Lessor] then adopted and assumed from IGM."); Tri-Continental Leasing Corp. v. Law Office of Richard W. Burns, 710 S.W.2d 604, 607 (Tex. Ct. App. 1985) (noting that the trial court referred to Tri-Continental [Lessor] as Supplier's "assignee"). 
Supplier is outside the scope of Article 9 in $A$ and $B$, but is subject to Article 9 in $C$. As a practical matter, Supplier in $A$ and $B$ is paid the entire purchase price at the outset, so it no longer cares if Lessee keeps up with its payments to Lessor, but Supplier in $C$ may be responsible to Lessor if Lessee does not pay. ${ }^{56}$

Another difference between the three alternatives turns on who is deemed the seller. In $A$, Lessee is treated as having bought the goods from Lessor, but in $B$ and $C$, Lessee is considered to have bought from Supplier. In $A$, therefore, Lessor is subject to the provisions of Article 2, while in $B$ and $C$, Supplier is subject to them. Consequently, Lessor is obligated to Lessee on any warranties that may exist in the sale in the case of $A$, but not in $B$ and $C .{ }^{57}$ Another effect, the focus of this Comment, is that in $A$, and sometimes $C$, but not in $B$, Lessor is also subject to rejection of the goods and to revocation of acceptance of the goods by Lessee. ${ }^{58}$

On the basis of these differences, it might seem straightforward to select the recharacterization that applies to any particular finance lease. These three interpretations, however, are also similar in several essential respects. First, their forms all reflect transactional structures that are in common use in commercial settings ${ }^{58}$ and therefore cannot be distinguished on the basis of commercial utility. In addition, any of the three scenarios could arise from a situation in which all three of the parties negotiated with each other and arranged for the steps in the transactions to occur substantially contemporaneously; thus, privity or simultaneity in the transactions is not necessarily a distinguishing factor. ${ }^{60}$ More important, however, these three alternative transactions

${ }^{66}$ Supplier will guarantee Lessee's payments if it sells its security interest to Lessor with recourse. See Levie, Security Interests in Chattel Paper, 78 YALE L.J. 935, 936-38 (1969), reprinted in 1C SECURED TRANSACTIONS UNDER THE UNIFORM Commercial Code (MB) 2877, 2879-82 (1988).

${ }^{57}$ In some $C$ assignment situations, however, Lessor's claim to payment may be subject to Lessee's defense that Supplier has not performed on its warranties. See King Louie, 597 S.W.2d at 644 (dissenting opinion) ("Funding Systems [Lessor] succeeded to the obligations for warranty, fair dealing and conscionability of contract that accrued to King Louie [Lessee] under the original terms of sale . . . ."); infra notes 171-73 and accompanying text.

s8 See infra note 64-147 and accompanying text.

${ }^{59}$ See Boss, supra note 1, at 57-58; Reisman, Assignment of Equipment Leases by Sale or as Collateral, in Leveraged LeAsing, supra note 2 , at 883, 884-87.

6o Privity and simultaneity would be relevant factors if the two steps involved in each of the three variants were taken independently and were separated by a substantial intervening period. It could then be argued more convincingly that no recharacterization is necessary and that the two steps should be treated independently, as structured by the parties. See King Louie, 597 S.W.2d at 632 ("The closely interrelated nature of all these steps as part of a single integrated transaction distinguishes this [finance lease] sharply from [a case in which the two transactions were separated by 
serve the same basic function and achieve the same basic result as a security interest finance lease. In all three, Lessee has bought the goods, although not necessarily from Supplier; Supplier has sold the goods, although not necessarily to Lessee; and Lessor has acquired a purchase money security interest in the goods. Furthermore, in all three cases, Lessor serves a financing function. Clearly, then, the three variants cannot be distinguished on the basis of the above criteria alone.

Similarly, finding the variant that is most similar in form to the transaction as structured by the parties is unhelpful. Variant $A$ in basic form resembles the basic finance lease, with the difference being that, in the finance lease, Lessor leases to Lessee, while in $A$ Lessor sells to Lessee. This is a simplistic analysis, however, because the basic finance lease can be structured in alternative ways to achieve the same basic object. Just as $A, B$, and $C$ describe three different situations in which the underlying transaction is a sale, there is a corresponding lease situation for each variant that closely follows its form:

$\left(A^{\circ}\right)$ Lessor, after buying the goods from Supplier, leases the goods to Lessee. ${ }^{01}$

(B') Lessee buys the goods from Supplier, then sells them to Lessor, who leases them back to Lessee. ${ }^{62}$

(C') Supplier leases the goods to Lessee, then assigns or sells its rights in the lease to Lessor.

The results in these three lease characterizations, as well as the three sales variants, are similar in three important ways: (i) Lessee acquires the use of the goods it selected; (ii) Supplier has sold the goods or rights in them; and (iii) Lessor is entitled to payments from Lessee, so that if Lessee should fail to make the payments, Lessor will have the power to remove the goods from Lessee's hands. Therefore, similarity of form should not be a basis for recharacterization.

Rather, in order to recharacterize a finance lease correctly, one needs to look beyond the form and basic function chosen by the parties to the total agreement between them. For example, the parties may have structured a basic finance lease, but intended that the supplier guarantee the finance lessee's payment of "rent" to the finance lessor. ${ }^{63}$

months]."). But see Addressograph-Multigraph Corp. v. Zink, 273 Md. 277, 281 \& n.3, 329 A.2d 28, 31 \& n.3 (1974) (invoking equitable estoppel to override the lack of privity when a lease was not executed until nearly two months after the equipment was sold and delivered).

o1 This is the basic finance lease as described in the Introduction. See supra notes 1-3 and accompanying text.

${ }^{62}$ This is a sale-and-leaseback.

${ }^{63}$ See, e.g., Freeman v. Hubco Leasing, Inc., 253 Ga. 698, 701 n.2, 324 S.E.2d 
Such a transaction might properly be recharacterized as an example of variant $C$ or $C^{\prime}$, depending on whether the lease is a security interest lease or a true lease, but only for purposes of the guarantee. Indeed, it is possible that in the same transaction the lessee may look to the lessor to perform on some of the warranties. Then, for purposes of performing on those warranties, the transaction more closely resembles variant $A$ or $A^{\prime}$.

If, however, the correct recharacterization of a particular transaction in a particular context depends upon the intent of the parties, then recharacterization is a method that assumes the result before the analysis is performed. It is more direct to determine separately what the parties intended with respect to each issue and apply that intent to the particular issue. Recharacterization, then, is at best a way to analogize the security interest finance lease to transactions that are squarely dealt with under Articles 2 and 9 or Article 2A.

\section{Revocation of Acceptance}

As discussed in Part $\mathrm{I}$, whether a finance lease is a true lease or a security interest lease determines whether Article 2A or Articles 2 and 9 of the Code govern. In either case, the Code provides for a remedy called revocation of acceptance. ${ }^{64}$ Although the provisions in Articles 2 and $2 \mathrm{~A}$ differ to a degree, they reflect a similar framework. ${ }^{65}$ That framework consists of the rules governing acceptance, rejection, cure, and revocation. Taken together, these goods-oriented concepts allow a party to a sale or lease contract to place the ultimate responsibility for the goods, in terms of ownership or the right to possession and use, on another party. ${ }^{68}$ The rules, stated briefly, work as follows: After a seller/lessor ${ }^{67}$ or supplier tenders delivery of the goods to the buyer/ lessee, the buyer/lessee has the option of accepting the goods or, if they are nonconforming, rejecting them. If the goods are rejected, the seller/

462, 466 n.2 (1985) ("Hub Motor [Supplier] signed the lease as guarantor, unconditionally guaranteeing to Hub Leasing [Lessor] full performance by Freeman [Lessee] of all his obligations.").

6s See U.C.C. \$§ 2-608, 2A-517.

Bs See id. $\S 2 \mathrm{~A}-101$ official comment ("Many of the provisions of [Article 2] were carried over, changed to reflect differences in style, leasing terminology or leasing practices.").

${ }^{66}$ See J. White \& R. Summers, Handbook of the Law Under the UnIFORM COMMERCIAL CODE $§ 8-1$ (2d ed. 1980).

${ }^{67}$ The terms "seller/lessor" and "buyer/lessee" are equivalent to "purported lessor" and "purported lessee," respectively. See supra note 19. These terms are introduced in this Part to underscore the similarities between Articles 2 and $2 \mathrm{~A}$ and to demonstrate the articles' separate applicability to different issues arising under a purported lease. 
lessor or supplier may have the opportunity to cure the nonconformity by making another tender of delivery. If the goods are eventually accepted, the buyer/lessee may still have recourse to revocation of acceptance if there is a nonconformity that substantially impairs the value of the goods. After rejection or revocation, the buyer/lessee may cancel the contract. ${ }^{68}$ The following discussion treats in detail acceptance, rejection, cure, and revocation, including the ways in which rejection and revocation may be limited, in the contexts of sales and true leases.

\section{A. Acceptance}

Acceptance of the goods is the first option available to a buyer/ lessee. It can occur only after the buyer/lessee has had a "reasonable opportunity to inspect the goods." "89 In addition, acceptance requires that the buyer/lessee either: (i) "signifies""70 or, optionally, in the case of a lease, "acts with respect to the goods in a manner that signifies," to the seller/lessor or supplier "that the goods are conforming or that [it] will take or retain them in spite of their nonconformity"72 or (ii) "fails to make an effective rejection."'7s In the case of a sale, acceptance also occurs if the buyer "does any act inconsistent with the seller's ownership" without regard to whether it had a reasonable opportunity to inspect. ${ }^{74}$ This last mode of acceptance was not incorporated into Article $2 \mathrm{~A}$, because the drafters considered it "irrelevant given the lessee's possession and use of the leased goods."'7s

\section{B. Rejection}

One important effect of acceptance is that it "precludes rejection of the goods accepted." ${ }^{\text {"re }}$ Subject to rules on installment contracts and contractual limitation of remedies, the buyer/lessee may reject the goods "if the goods or the tender or delivery fail in any respect to conform" to the contract. ${ }^{77}$ Because the buyer/lessee may reject the goods if any aspect of the tender is nonconforming, the Article 2 provision has been

e8 See generally J. WhITE \& R. Summers, supra note 66, §§ 8-1 to 8-4 (discussing rejection, revocation of acceptance, cure, and acceptance).

${ }^{6 \theta}$ U.C.C. $\$ \S 2-606(1)(a), 2 A-515(1)$.

${ }^{70}$ Id. $\S \S 2-606(1)(\mathrm{a}), 2 \mathrm{~A}-515(1)(\mathrm{a})$.

${ }^{71}$ Id. $\S 2 \mathrm{~A}-515(1)(\mathrm{a})$.

${ }^{72} I d$. $\S \S 2-606(1)(\mathrm{a}), 2 \mathrm{~A}-515(1)(\mathrm{a})$.

73 Id. $\S \S 2-606(1)(\mathrm{b}), 2 \mathrm{~A}-515(1)(\mathrm{b})$.

${ }^{74} I d . \S 2-606(1)(c)$.

75 Id. § $2 \mathrm{~A}-515$ official comment.

${ }^{78} I d$. $\S \S 2-607(2), 2 A-516(2)$.

77 Id. § 2A-509(1); see also id. § 2-601 (employing "tender of delivery" instead of "tender or delivery"). 
said to embody the "perfect tender rule."78

The perfect tender rule follows from the definition of "conforming": Goods or performance under a contract are "conforming" when they are "in accordance with the obligations under" the contract. $^{20}$ This self-evident statement seems to leave little or no room for interpreting as "conforming" goods or performance that are merely substantially or essentially in accordance with the obligations under the contract. However, the official comment elaborates:

It is in general intended to continue the policy of requiring exact performance by the seller of his obligations as a condition to his right to require acceptance. However, the seller is in part safeguarded against surprise as a result of sudden technicality on the buyer's part by the provisions of Section 2-508 on seller's cure of improper tender or delivery. Moreover usage of trade frequently permits commercial leeways in performance and the language of the agreement itself must be read in the light of such custom or usage and also, prior course of dealing, and in a long term contract, the course of performance. ${ }^{80}$

Many commentators have also noted that the perfect tender rule is but "a mere shadow of its formerly robust self." Indeed, there are several ways in which the perfect tender rule is weakened by other

78 See Peters, Remedies for Breach of Contracts Relating to the Sale of Goods Under the Uniform Commercial Code: A Roadmap for Article 2, 73 YaLE L.J. 199, 206 (1963).

79 U.C.C. $\S \S 2-106(2), 2 A-103(1)(d)$.

so Id. § 2-106 official comment. Because this principle can be applied to leases as well, this statement of policy is incorporated by reference into $\S 2 \mathrm{~A}-103$. See id. $\S 2 \mathrm{~A}-$ 101 official comment ("TT]he official comments to those sections of Article 2 whose provisions were carried over are incorporated by reference in Article 2A."). The weight to be given such a statement of policy is considerable, see E. FARNSWORTH \& J. HONNOLD, CASES AND MATERIALS ON COMMERCIAL LAW 8-11 (4th ed. 1985), especially when there is no conflict between the text and the official comment, see infra notes 8185 and accompanying text.

${ }^{81}$ Peters, supra note 78, at 206; see also B. GlaRK \& C. SMITH, The LAw of Product Warranties, II 7.02[2], at 7-11 (1984) ("Indeed, the courts rarely give full effect to the perfect tender rule."); J. WhITE \& R. SummerS, supra note 66, \& 8-3, at 304 (noting that "even before enactment of the Code, the perfect tender rule was in decline"); Comment, Substantial Performance: The Real Alternative to Perfect Tender Under the U.C.C., 12 Hous. L. REv. 437, 440-41 (1975) (crediting the Code with mitigating the harsh effects of the absolute perfect tender rule); Note, Uniform Commercial Code-Sales-Sections 2-508 and 2-608-Limitations on the Perfect-Tender Rule, $69 \mathrm{MrCH}$. L. REv. 130, 132 (1970) (noting that the Code expressly limits the perfect tender rule embodied in $\S 2-601$ with Code provisions such as $\S \S 2-612,2-718$, and 2-719). 
provisions of the Code. First, as mentioned in the offical comment, ${ }^{82}$ a seller/lessor may be able to avail itself of the cure provisions, which are discussed below. ${ }^{83}$ The perfect tender rule is further weakened by special rules concerning commercial impracticability. ${ }^{84}$ Finally, in addition to any applicable trade usage, course of dealing, or course of performance, the obligation of good faith that is read into every contract will also prevent rejection for bad faith reasons. With these rules, courts are given substantial latitude to find a rejection unwarranted in the circumstances. $^{85}$

In order to make an effective rejection, the buyer/lessee must make the rejection "within a reasonable time" after tender or delivery of the goods and "seasonably notif[y]" the seller/lessor of the rejection. ${ }^{86}$ If the rejection is not effective, then acceptance results. ${ }^{87}$ Even if the rejection is effective, however, the seller/lessor may have the option to cure the nonconformity, if it can, and make another tender of goods.

\section{Cure}

If "the time for performance has not yet expired," the seller/lessor or supplier may "seasonably notify the [buyer/lessor] of [its] intention to cure" and then "make a conforming delivery" within the time provided in the contract. ${ }^{88}$ Furthermore, even though the contract time may have expired, if the seller/lessor or supplier "had reasonable grounds to believe [that the non-conforming tender] would be acceptable with or without money allowance," then it may have "a further reasonable time to substitute a conforming tender" if it "seasonably notifies the [buyer/lessee]."

82 See U.C.C. § 2-106 official comment.

8s See infra notes 88-91 and accompanying text.

s4 See U.C.C. $\S \S 2-614$ to $-616 ; i d$. $\S \S 2 A-404$ to -406 ; see also United Equities Co. v. First Nat'l City Bank, 52 A.D.2d 154, 162, 383 N.Y.S.2d 6, 12 (1976) (basing on $\S 2-614$ a decision to allow defendant seller to provide a "commercially reasonable substitute" despite the buyer's desire to reject the nonconforming goods), affd, 41 N.Y.2d 1032, 363 N.E.2d 1385, 395 N.Y.S.2d 640 (1977).

${ }^{8 s}$ See B. Clark \& G. SMTTH, supra note 81, II 7.02[2], at 7-11 ("When the breach involves only a minor nonconformity, many courts do not hesitate to carve out a de minimus exception to the general rule."); J. WHITE \& R. SuMmers, supra note 66, $\S 8-3$, at 304-05 ("We conclude . . . the law would be little changed if 2-601 gave the right to reject only upon 'substantial' nonconformity."). But see H. GreENBERG, RIGHTS AND REMEDIES UNDER U.C.C. ARTICLE 2, at 323 \& n.66 (1987) (suggesting that the degree of nonconformity necessary for rejection may still be less than that required for revocation).

${ }^{86}$ U.G.C. $\$ \S 2-602(1), 2 A-509(2)$.

${ }^{87}$ See id. $\$ \S 2-606(1)(\mathrm{b}), 2 \mathrm{~A}-515(1)(\mathrm{b})$.

${ }^{88} I d$. $\S \S 2-508(1), 2 \mathrm{~A}-513(1)$.

${ }^{89} I d . \S \S 2-508(2), 2 A-513(2)$. 
provision "seeks to avoid injustice to the seller by reason of a surprise rejection by the buyer." ${ }^{300}$ If the seller/lessor or supplier had reasonable grounds to believe, perhaps through a prior course of dealing, course of performance, or usage of trade, that the buyer/lessee would accept the nonconforming tender, perhaps at a reduced price, then it is allowed another chance to tender conforming goods, and is given a reasonable time in which to do so. ${ }^{91}$

\section{Revocation}

Finally, even after a buyer/lessee accepts, either directly or through an ineffective rejection, it may still resort to revocation of acceptance. The terms of the revocation provisions, however, make much more restrictive the availability of revocation as a remedy when compared with rejection. ${ }^{92}$ In order to revoke acceptance, several conditions must be satified. First, the nonconformity of the goods must "substantially" impair their value to the buyer/lessor who is not a finance lessee. ${ }^{93}$ Second, if the buyer/lessor knew of the nonconformity, but ac-

${ }^{80}$ Id. $\S 2-508$ official comment; see also supra note 80 (discussing the applicability of the $\S 2-508$ official comment to $\S 2 A-513$ ).

${ }^{21}$ See id. \$ 2-508 official comment; see also, e.g., North Am. Steel Corp. v. Siderius, Inc., 75 Mich. App. 391, 400, 254 N.W.2d 899, 904 (1977) (recognizing that trade usage acts as a contractual limitation of the rejection remedy under $\S 2-508$ ); Meads v. Davis, 22 N.C. App. 479, 481, 206 S.E.2d 868, 869 (1974) (interpreting $\S 2-508(2)$ and giving an example of when a seller may knowingly send a nonconforming good to a buyer).

92 Section 2A-517 (Revocation of Acceptance of Goods) provides in full that:

(1) A lessee may revoke acceptance of a lot or commercial unit whose nonconformity substantially impairs its value to the lessee if he [or she] has accepted it:

(a) except in the case of a finance lease, on the reasonable assumption that its nonconformity would be cured and it has not been seasonably cured; or

(b) without discovery of the nonconformity if the lessee's acceptance was reasonably induced either by the lessor's assurances or, except in the case of a finance lease, by the difficulty of discovery before acceptance.

(2) Revocation of acceptance must occur within a reasonable time after the lessee discovers or should have discovered the ground for it and before any substantial change in condition of the goods which is not caused by the nonconformity. Revocation is not effective until the lessee notifies the lessor.

(3) A lessee who so revokes has the same rights and duties with regard to the goods involved as if the lessee had rejected them.

Section 2-608 (Revocation of Acceptance in Whole or in Part) applies to buyers and sellers, rather than lessees and lessors, and does not refer to finance leases; otherwise, its language is similar.

${ }_{93}$ U.C.C. $\S \S 2-608(1), 2 A-517(1)$.

The official comment notes that "the question is whether the non-conformity is such as will in fact cause a substantial impairment of value to the buyer though the 
cepted on the assumption that it would be cured, the assumption must have been "reasonable" and the nonconformity not seasonably cured. ${ }^{94}$ If, on the other hand, the buyer/lessor accepted without knowing of the nonconformity, in order to revoke, the acceptance must have been "reasonably induced" either by the difficulty of discovery before acceptance or by the seller/lessor's assurances. ${ }^{95}$ Furthermore, for revocation to be effective, it must occur within a "reasonable time," and the buyer/ lessee must notify the seller/lessor, ${ }^{96}$ as is required for rejection. The time taken to revoke is measured from the time the buyer/lessee actually discovered or should have discovered the ground for revocation, but the "reasonable time" period may be shortened if there is "any substantial change in condition of the goods which is not caused by" the defects or nonconformity. ${ }^{97}$

For true finance lessees, the conditions for revocation are even more restrictive. A finance lessee cannot revoke if it knew of the nonconformity before acceptance. ${ }^{98}$ Nor can it revoke on the ground that it had not discovered the nonconformity before acceptance, if that acceptance had been induced only by the difficulty of discovery; in such a situation, it would not matter whether the acceptance had been reasonably induced. ${ }^{9 \theta}$ A finance lessee may revoke acceptance only if it had not discovered the nonconformity and only if acceptance had been reasonably induced by the finance lessor's assurances. ${ }^{100}$

Another significant way in which rejection and revocation differ is in the opportunity to cure. While rejection permits the seller/lessor or supplier to cure the nonconformity, ${ }^{101}$ revocation does not. ${ }^{102}$ Thus,

seller had no advance knowledge as to the buyer's particular circumstances." Id. § 2608 official comment. Nevertheless, White and Summers do not believe that a single, objective test, without reference to the particular buyer, would make much of a difference. See J. White \& R. Summers, supra note 66, § 8-3, at 309 (stating that "we suspect that a single standard of objective 'substantial nonconformity' will cover $99.44 \%$ of all rejection and revocation cases").

os See U.C.C. $\$ \S 2-608(1)(a), 2 A-517(1)(a)$.

${ }^{98} I d$. §§ 2-608(1)(b), 2A-517(1)(b).

${ }^{\circ} I d$. $\S \S 2-608(2), 2 \mathrm{~A}-517(2)$.

${ }_{97}$ Id. $\S \S 2-608(2), 2 \mathrm{~A}-517(2)$; see also Royal Business Machs., Inc. v. Lorraine Corp., 633 F.2d 34, 48 (7th Cir. 1980) (requiring that the revocation occur within a reasonable time and before any substantial change in the condition of the goods); Fargo Mach. \& Tool Co. v. Kearney \& Trecker Corp., 428 F. Supp. 364, 381 (E.D. Mich. 1977) (holding that the use and depreciation of the good constituted a substantial change in the good's condition not caused by its own defects, so that revocation was barred).

${ }_{98}$ See U.C.C. § 2A-516(2).

99 See id. § $2 A-517(1)(\mathrm{b})$.

100 See id. \$ 2A-517(1).

101 See id. §§ 2-508, 2A-513.

102 See id. $\S \S 2-608,2 A-517$. For cases discussing revocation in the sales context, see, e.g., Jensen v. Seigel Mobile Homes Group, 105 Idaho 189, 193, 668 P.2d 65, 69- 
once revocation has taken place or the "reasonable time" in which revocation must occur has passed, the parties may no longer make use of these goods-oriented principles to shift ownership of, or responsibility for, the goods back and forth among themselves.

In addition, burdens of proof differ in rejection and revocation. ${ }^{103}$ After a rejection, the seller/lessor has the burden to show that the goods and their tender conformed to the contract; after a revocation, the buyer/lessee must establish any breach or default by the seller/ lessor. ${ }^{104}$

After an effective revocation, as after a rejection, the buyer/lessee may treat the seller/lessor as having breached ${ }^{105}$ or defaulted on ${ }^{106}$ the contract. Consequently, it may seek various remedies, such as return of that part of the purchase price already paid ${ }^{\mathbf{1 0 7}}$ and reimbursement for cover. ${ }^{108}$ If, on the other hand, a nonconformity surfaces after the time for revocation has expired, then the buyer/lessee may have recourse for breach of warranty. ${ }^{108}$ Although the buyer/lessee will have recourse for nonconforming goods in either case, after rejection or revocation, it will no longer own, or be responsible for the rent for, the defective goods. This is especially important if the seller/lessor or supplier is unable, perhaps because of bankruptcy, or unwilling to remedy the nonconformity or pay damages. In a three-party transaction, such as a true or security interest finance lease, being able to reject or revoke may allow the finance lessee to place the ensuing loss on the finance lessor. ${ }^{\mathbf{1 1 0}}$ This

70 (1983) ("TT]he Uniform Commercial Code does not allow a seller the right to cure defects following a buyer's acceptance [and revocation] of the goods." (citing Bonebrake v. Cox, 499 F.2d 951 (8th Gir. 1974); Linscott v. Smith, 3 Kan. App. 2d 1, 587 P.2d 1271 (1978); Note, supra note 78)); Diversified Human Resources Group, Inc. v. PBKBB, Inc., 671 S.W.2d 634, 638 (Tex. Ct. App. 1984) (noting that, after revocation, "the seller does not have a right to cure by repairs or replacement" (citing Gappelberg v. Landrum, 666 S.W.2d 88 (Tex. 1984))).

103 See H. GreenberG, supra note 85, $\$ 21.22$, at 323 \& nn.67-68.

104 See U.C.C. $\$ \S 2-607(4), 2 A-516(3)$ (c); see also Printing Center of Tex., Inc. v. Supermind Publishing Co., 669 S.W.2d 779, 784 (Tex. Ct. App. 1984) (placing on the seller the burden of proving wrongful rejection); Ramirez v. Autosport, 88 N.J. $277,289,440$ A.2d 1345, 1351 (1982) (placing on the buyer the burden of proving a nonconformity sufficient to justify revocation).

It is likely that a similar distribution of burdens would apply to leases, because the rules governing sales serve as persuasive authority for courts interpreting Article $2 \mathrm{~A}$. See U.C.C. $\$ 2 \mathrm{~A}-101$ official comment ("[A]ny case law interpreting lprovisions of Article 2 that were carried over] should be viewed as persuasive but not binding on a court when deciding a similar issue with respect to leases.").

${ }^{10 s}$ See U.C.C. \& 2-711(1).

${ }^{108}$ See $i d . \S 2 A-508(1)$.

${ }^{207}$ See id. \$§ 2-711(1), 2A-508(1)(b).

${ }^{108}$ See id. $\S \S 2-711(1)(\mathrm{a}), 2 \mathrm{~A}-508(1)(\mathrm{c})$.

109 See id. $\S \S 2-714(2), 2 A-519(4)$.

110 If the finance lease is a true lease, then $\S 2 \mathrm{~A}-508(1)$ will apply; if it is a 
is the principal concern regarding rejection and revocation in finance leases.

Because it occurs later in the course of the transaction and is more restricted in operation than rejection, revocation of acceptance is a remedy that is usually thought to be an extension of the right to reject. ${ }^{111}$ Revocation is, in a sense, simply a later form of rejection. ${ }^{112}$ Specifically, the Code provides that a buyer/lessee who revokes "has the same rights and duties with regard to the goods involved as if [it] had rejected them."113 Because revocation of acceptance comes later, however, it should not be surprising that the requirements for revocation are more exacting than those for rejection, ${ }^{114}$ for the longer the buyer/lessee keeps the goods, the more likely it is that any defects were caused or aggravated by the buyer/lessee, rather than having been present at delivery. ${ }^{115}$ It is also more possible that the goods have depreciated in value or that the buyer/lessee has benefited from use of the goods. ${ }^{116}$ This may explain why, although the degrees of nonconformity required for rejection and revocation are very similar in practice, ${ }_{2}^{117}$ the opportunity to invoke the latter remedy is more limited.

It has been suggested, convincingly, that the possibility of revocation after acceptance renders workable the perfect tender rule as embodied in Articles 2 and $2 A .^{118}$ If revocation were not available, then rejection would be used more frequently, and for relatively minor nonconformities. In view of the complexity of many modern goods and the prohibitive costs of thoroughly inspecting such goods at delivery, rejection for insubstantial nonconformities would be used by buyer/lessees to gain time to examine goods further while the goods remained in their

security interest lease, then $\S 2-711(1)$ will apply.

111 See Johnson v. GMC, Chevrolet Motors Div., 233 Kan. 1044, 1046, 668 P.2d 139,142 (1983) ("Rejection is the buyer's refusal to keep delivered goods . . . . Revocation of acceptance is a refusal to keep delivered goods that occurs after a buyer has accepted and the time for rejection has expired.").

${ }_{112}$ See Ramirez v. Autosport, 88 N.J. 277, 288, 440 A.2d 1345, 1350-51 (1982) ("Revocation of acceptance is like rejection, but occurs after the buyer has accepted the goods.").

113 U.C.C. $\S \S 2-608(3), 2 A-517(3)$.

114 See Johnson, $233 \mathrm{Kan}$. at 1046, 668 P.2d at 142 ("The right to reject goods is a remedy that is more available since rejection occurs prior to the buyer's acceptance."); Ramirez, 88 N.J. at 286, 440 A.2d at 1349 ("After acceptance, the Code strikes a different balance: the buyer may revoke acceptance only if the nonconformity substantially impairs the value of goods to him.").

11 See J. White \& R. Summers, supra note 66, § 8-3, at 301.

116 See id.

117 See supra notes 81-85 and accompanying text.

118 See General Elec. Gredit Corp. v. Ger-Beck Mach. Co., 806 F.2d 1207, 1216 (3d Cir. 1986) (dissenting opinion) (citing Peters, supra note 78, at 206-08). 
possession. ${ }^{119}$ By delaying acceptance, the buyer/lessee may increase the chance that important defects will come to light in the interval before the seller/lessor's cure. Allowing for the possibility of a later revocation for a nonconformity that substantially impairs the value of the goods eliminates this type of posturing by preserving the buyer/ lessee's right to return the goods. Consequently, recognizing the right to revoke acceptance serves to "simplify, clarify and modernize the law governing commercial transactions"120 and "to permit the continued expansion of commercial practices through custom, usage and agreement of the parties."121

\section{E. Limiting Revocation}

Both rejection and revocation turn on nonconformity in the goods or the seller/lessor's performance. If the goods conform and the performance is satisfactory, and both "are in accordance with the obligations of the contract,"122 the buyer/lessee has no cause to reject or revoke. Therefore, if the seller/lessor makes no representations in the contract and disclaims all warranties, ${ }^{123}$ it may be able to require the buyer/lessee's acceptance. ${ }^{124}$ Alternatively, it may be able to limit the remedies available to the buyer/lessee so as to preclude revocation of acceptance or even rejection. Nevertheless, there are a few pitfalls associated with either course of action.

First, consider limitation of remedies. The Code sets up no obstacles to limiting rejection or revocation specifically. For example, a seller may limit the buyer's remedies to replacement or repair. ${ }^{\mathbf{1 2 5}}$ Indeed, the

11 Rejected goods generally remain in the buyer/lessee's hands while awaiting the seller/lessor's disposition. See U.C.C. $\S \S 2-602$ to $-604 ; i d$. $\S \S 2 A-511$ to -512 .

${ }^{120} I d$. $\$ 1-102(2)(\mathrm{a})$.

121 Id. $\$ 1-102(2)(\mathrm{b})$.

$122 I d$. $\S 2-106(2)$.

${ }^{123}$ See id. $\S \S 2-316,2 \mathrm{~A}-214$ (Exclusion or Modification of Warranties).

124 See H. GREENBERG, supra note 85, $\S 21.23$, at 323 (noting that if the seller disclaims all express or implied warranties, "[b]oth rejection and revocation are precluded despite the existence of what ordinarily would have been a defect in the goods if the goods had been expressly or impliedly warranted"); see also B. CLARK \& C. SMITH, supra note 81,7 7.03[4], at 7-33 ("[W] Wen the seller effectively disclaims warranty liability, there is no longer a right for which revocation can serve as a remedy."). But see Frantz Lithographic Serv., Inc. v. Sun Chem. Corp., 38 U.C.C. Rep. Serv. (Gallaghan) 485, 487 (E.D. Pa. 1984) (holding that warranty disclaimers do not bar revocation when there is a substantial impairment in the value of the goods); Blackenship v. Northtown Ford, Inc., 95 Ill. App. 3d 303, 306-07, 420 N.E.2d 167, 171 (1981) (holding that "revocation of acceptance is appropriate even if the dealer has properly disclaimed all implied warranties").

125. Under Article 2, a buyer's right to reject is expressly made subject to contractual limitations on remedies. See U.C.C. $\S 2-601$; see also H. GREENBERG, supra note $85, \S 21.23$, at 324 (stating that a seller may limit the buyer's remedy exclusively to 
general provisions governing limitation of remedies allow the agreement between the parties to provide for remedies "in substitution for those provided"126 in the Code, and they may be "exclusive."127 When, however, "circumstances cause an exclusive or limited remedy to fail of its essential purpose, remedy may be had as provided in this Act,"128 which may include rejection or revocation. Furthermore, the Code gives courts the power to invalidate unconscionable contract provisions. ${ }^{129}$ That power, by implication, would also enable a court to allow rejection or revocation if a limitation on remedies is held unconscionable. The official comment explains:

[It] is of the very essence of a sales contract that at least minimum adequate remedies be available. If the parties intend to conclude a contract for sale within [Article 2] they must accept the legal consequence that there be at least a fair quantum of remedy for breach of the obligations or duties outlined in the contract. ${ }^{130}$

This policy has been applied to leases as well. ${ }^{131}$ Article $2 \mathrm{~A}$ adopts this position. ${ }^{\text {132 }}$

The Code recognizes three types of warranties under which a buyer/lessee may claim a nonconformity in the goods: implied warranties, ${ }^{133}$ express warranties, ${ }^{134}$ and, in the case of sales, the warranty of title ${ }^{135}$ or, in the case of leases, the warranty against interfer-

the repair or replacement of the goods sold); $i d$. $\$ 15.20$, at 244-45 (stating that limitations of the buyer's remedies must be articulated in the contract of sale in "clear and unambiguous language"); of. Reynolds Metals Co. v. Westinghouse Elec. Corp., 758 F.2d 1073, 1074 n.1 (5th Cir. 1985) (allowing a contractual disclaimer of warranties that limited the seller's liability to replacement or repair, but deciding on another ground). Although Article $2 \mathrm{~A}$ does not contain such an express provision, such an interpretation would not be inconsistent with it. See U.C.C. § 2A-509.

128 U.C.C. $\S \S 2-719(1), 2 A-503(1)$.

127 Id. $\S \S 2-719(2), 2 A-503(2)$.

128 Id. $\S 2-719(2)$. Section $2 A-503(2)$ employs similar language.

129 See id. $\$ \S 2-302,2 A-108$.

1so Id. § 2-719 official comment.

131 See Freeman v. Hubco Leasing, Inc., $253 \mathrm{Ga}$. 698, 705-06, 324 S.E.2d 462, 469-70 (1985) (ruling that a finance lessee could revoke acceptance, even though the lease had contemplated only replacement or repair, when the replacement and repair had been repeatedly inadequate).

132 See U.C.C. § 2A-503(2) ("If circumstances cause an exclusive or limited remedy to fail of its essential purpose, or provision for an exclusive remedy is unconscionable, remedy may be had as provided in this Article."); see also id. $\S 2 \mathrm{~A}-503$ official comment ("Subsection (2) makes explicit with respect to [Article 2A] what is implicit in Section 2-719 with respect to the Article on Sales (Article 2): if an exclusive remedy is held to be unconscionable, remedies under this Article are available.").

${ }^{133}$ See id. $\S \S 2-314,2-315,2 \mathrm{~A}-212,2 \mathrm{~A}-213$.

134 See $i d . \S \S 2-313,2 A-210$.

135 See id. § 2-312. 
ence. ${ }^{136}$ These warranties may be disclaimed in different ways. Implied warranties generally can be excluded with expressions such as "as is" or "with all faults."137 The warranty of title or the warranty against interference may be disclaimed by "specific" language to that effect. ${ }^{138}$ Express warranties, in contrast, are more difficult to disclaim. ${ }^{139}$ One reason is that " $[w]$ ords or conduct relevant to the creation of an express warranty and words or conduct tending to negate or limit a warranty shall be construed wherever reasonable as consistent with each other." 140 The other reason is that "negation or limitation is inoperative to the extent that the construction is unreasonable."141 The latter provision is tempered, ${ }^{142}$ however, by the sections on parol or extrinsic evidence, which allow the exclusion of "evidence of any prior agreement or of a contemporaneous oral agreement."143

It would thus seem best not to give express warranties in the first place. However, in identifying a good as, say, a "car," one may be creating an express warranty that a good conforming to this general description will be tendered. Whether the good must be capable of conveying passengers on a highway or whether the seller/lessor has only described the good's general nature and function, rather than expressly characterized its quality, some representation by the seller/lessor has occurred. ${ }^{144}$ Consequently, should something totally different, like a wooden box, be tendered, the good would not conform to the contract. ${ }^{145}$

The apparently similar concept of "total failure of performance" has been used to make inapplicable disclaimers of warranties. In one case, the seller failed to send a competent service engineer to install the purchased machinery for the buyer, as required by the contract. The machinery was improperly installed and damage resulted. The court

136 See id. § 2A-211.

137 See id. $\S \S 2-316(3)(\mathrm{a}), 2 \mathrm{~A}-214(3)(\mathrm{a})$.

${ }^{138}$ See $i d$. $\S \S 2-312(2), 2 A-214(4)$.

139 See id. $\S \S 2-316(1), 2-317,2 A-214(1), 2 A-215$; see also J. WhITE \& R. SuMMERS, supra note $66, \S \S 12-1$ to -4 (discussing disclaiming of express warranties); $c f$. id. $\S 12-7$ (discussing cumulation and conflict of warranties). limit").

140 U.C.C. $\S 2 A-214(1)$; see also id. § 2-316(1) (omitting " $a$ " after "negate or

${ }^{141}$ Id. § 2A-214(1); see also id. § 2-316(1) (employing "such construction" instead of "the construction").

142 See id. $\S \S 2-316(1), 2 A-214(1)$ (subjecting the operation of negation and limitation to the provisions on parol and extrinsic evidence).

${ }^{143} I d$. $\$ \S 2-202,2 \mathrm{~A}-202$.

144 See J. White \& R. Summers, supra note 66, § 9-3, at 331-32.

145 See Tacoma Boatbuilding Co. v. Delta Fishing Co., 28 U.C.C. Rep. Serv. (Callaghan) 26, 32-33 (1980). 
ruled that:

If [the seller] had provided a competent engineer . . . and that engineer had not performed as expected, there would be a breach of warranty . . . In contrast, if [the engineer had not been qualified], then by supplying him [the seller] failed to perform at all as promised under the contract. Such a failure would constitute a total failure of performance, a breach of contract for which the warranty disclaimer would not protect $[$ the seller] . . . 146

Conceivably, failure of performance in some circumstances, even in the presence of valid warranty disclaimers, may suffice to justify revocation. ${ }^{147}$

In summary, revocation of acceptance is an integral part of the remedies envisaged in Articles 2 and 2A. Along with the cure provisions, revocation serves to temper the perfect tender rule of rejection. Without revocation, buyers and lessors may be more inclined to reject goods for trivial reasons, thereby burdening commercial practices. Therefore, in determining whether a lease or sale allows for revocation, it is important that great weight be given to what the parties actually bargained for. Because one would not expect a party to bargain away all of its remedies, courts occasionally find that the lessee or buyer reserved the right to reject or revoke, even when the contract may be interpreted otherwise. Given these considerations, this Comment suggests that, when a finance lease lacks a specific provision concerning revocation, or is unclear in that respect, some form of revocation should be preserved. Part III demonstrates that the framework provided by Article $2 \mathrm{~A}$ for dealing with finance leases is reasonable for both true and security interest finance leases.

Cir. 1985).

${ }^{146}$ Reynolds Metals Co. v. Westinghouse Elec. Corp., 758 F.2d 1073, 1078 (5th

${ }^{147}$ Indeed, one Court of Appeals judge has equated the concepts. See General Elec. Credit Corp. v. Ger-Beck Mach. Co., 806 F.2d 1207, 1214 (3d Cir. 1986) (dissenting opinion) ("Because the lathe was substantially nonconforming, there has been a failure of consideration and [the lessee] has the right under Article Two to revoke its acceptance."); see also Tri-Continental Leasing Corp. v. Law Office of Richard W. Burns, 710 S.W.2d 604, 606 (Tex. Ct. App. 1985) (ruling disclaimer provisions in a finance lease agreement to be unconscionable because the copying machine's incapability of performing its intended function constituted "complete failure of consideration," so that the contract was "rescinded"). 


\section{The True Finance Lease Versus the Security Interest Finance Lease}

This Part first examines the type of finance lease transaction contemplated by Article $2 \mathrm{~A}$ and how it relates to the limited opportunity for a lessee to seek revocation of acceptance against the finance lessor. The Article 2A approach to true finance leases is then compared with the analyses of security interest finance leases advanced by the majority and the dissent in General Electric Credit Corp. v. Ger-Beck Machine Co. $(G E C C) .{ }^{148}$ This Part concludes that the treatment of true finance leases provided in Article 2A also should be adopted for security interest leases.

\section{A. The True Finance Lease}

The true finance lease, as contemplated by Article 2A, envisions the finance lessor as serving only a financing function. This is reflected in the article's definition of the terminology associated with finance leases and in the article's operation on the parties, particularly with respect to transfer of the benefit of the supply contract, irrevocability of the lessee's promises, warranties, risk of loss, and acceptance, rejection, and revocation.

\section{Definitions}

The definitions pertinent to finance leases are collected in section 2A-103(1). First, the finance lease is a "lease," 148 while a "lease" is a "transfer of the right to possession and use of goods for a term in return for consideration," not including a sale or security interest. ${ }^{150}$ In addition, the parties to a lease, the "lessee" and the "lessor," will be parties to both a "lease agreement" and a "lease contract." A "lease agreement" is "the bargain, with respect to the lease, of the lessor and the lessee." 151 A "lease contract" is "the total legal obligation that results from the lease agreement."'182 In a finance lease, there is also a "supply contract" as well as a "supplier." The "supplier" is the "person from whom a lessor buys or leases goods to be leased under a finance lease."163 The "supply contract" is the "contract under which a

148806 F.2d 1207 (3d Gir. 1986).

148 See U.C.C. § 2 A-103(1)(g).

${ }^{160}$ Id. $\S 2 \mathrm{~A}-103(1)(\mathrm{j})$.

151 Id. \& $2 \mathrm{~A}-103(1)(\mathrm{k})$.

162 Id. $\S 2 \mathrm{~A}-103(1)(l)$.

${ }^{163} I d$. $\S 2 \mathrm{~A}-103(1)(\mathrm{x})$. 
lessor buys or leases goods to be leased."154

From these definitions, it would appear that in a sale-and-leaseback, a kind of finance lease, ${ }^{155}$ the supplier and the lessee would be the same person. Such a reading, however, would render redundant and inconsistent those later sections of Article 2A that refer to the supplier. ${ }^{156}$ It would also not make sense for there to be no supplier in a sale-and-leaseback. Consequently, it must be that in a sale-and-leaseback, the "supplier" is the third party from whom the finance lessee first obtained the goods before selling the goods and assigning its rights to the finance lessor. Similarly, the "supply contract" in the case of a sale-and-leaseback must be the contract between the third-party supplier and the finance lessee that was later assigned to the finance lessor.

In addition to satisfying the article's definition of a lease, a "finance lease" must meet three additional requirements. These requirements ensure that the finance lessor's primary role is to provide financing. First, the lessor must not serve a function of producing or dealing in the goods; second, it must have obtained the goods in connection with the lease; and third, either the lessee sees the supply contract before signing the lease contract or its approval of the supply contract is required before the lease contract can be binding on it. ${ }^{157}$ The official comment contemplates that:

[t]he supplier manufactures or supplies the goods pursuant to the lessee's specification, perhaps even pursuant to a purchase order, sales agreement or lease agreement between the supplier and the lessee. After the prospective finance lease is negotiated, a purchase order, sales agreement, or lease agreement is entered into by the lessor (as buyer or prime lessee) or an existing order, agreement or lease is assigned by the lessee to the lessor, and the lessor and the

$154 I d . \S 2 \mathrm{~A}-103(1)(\mathrm{y})$. text.

155 See id. $\S 2 \mathrm{~A}-103(\mathrm{~g})$ official comment; supra notes $2 \& 62$ and accompanying

${ }^{166}$ See, e.g., U.C.C. $§ 2 \mathrm{~A}-209$ (Lessee Under Finance Lease as Beneficiary of Supply Contract); see also infra notes 162-70 and accompanying text (discussing the transfer to the lessee of the supplier's obligations under the supply contract).

${ }^{167}$ The text of the provision states:

"Finance lease" means a lease in which (i) the lessor does not select, manufacture or supply the goods, (ii) the lessor acquires the goods or the right to possession and use of the goods in connection with the lease, and (iii) either the lessee receives a copy of the contract evidencing the lessor's purchase of the goods on or before signing the lease contract, or the lessee's approval of the contract evidencing the lessor's purchase of the goods is a condition to effectiveness of the lease contract.

U.C.C. $\S 2 \mathrm{~A}-103(\mathrm{~g})$. 
lessee then enter into a lease or sublease of the goods. ${ }^{158}$

The official comment further notes that the lessee is to look almost solely to the supplier for representations, covenants, and warranties, but the lessor may undertake to perform on some of these obligations.

The official comment explains the reasons for the three requirements. That the lessor does not select, manufacture, or supply the goods justifies "releasing the lessor from most of its traditional liability."169 Requiring that the goods or the rights to their use be acquired by the lessor in connection with the lease "insure[s] the lessee's [sole] reliance on the supplier."160 Consequently, because the lessee is to look almost entirely to the supplier for representations, covenants, and warranties, the lessee is bound by the lease agreement only if it first sees or later approves of the supply contract. ${ }^{162}$

\section{Redirecting the Obligations}

Section 2A-209 makes explicit what the official comment mentions in section $2 \mathrm{~A}-103(\mathrm{~g})$ : The finance lessee is the beneficiary of the supply contract. Subsection (1) states:

The benefit of the supplier's promises to the lessor under the supply contract and of all warranties, whether express or implied, under the supply contract, extends to the lessee to the extent of the lessee's leasehold interest under a finance lease related to the supply contract, but subject to the terms of the supply contract and all of the supplier's defenses or claims arising therefrom. ${ }^{162}$

The official comment explains that this provision is self-executing and, as a matter of policy, may not be excluded, modified, or limited. ${ }^{\mathbf{1 6 3}}$ Consequently, "selective discrimination" against the finance lessee, meaning "exclusion of the supplier's liability to the lessee with respect to warranties made to the lessor," is precluded. ${ }^{164}$

Subsection (2) limits the effect on the parties of the extension of the benefit by providing that subsection (1) "does not: (a) modify the rights and obligations of the parties to the supply contract, whether arising therefrom or otherwise, or (b) impose any duty or liability

${ }^{188}$ Id. $\S 2 \mathrm{~A}-103$ (g) official comment.

${ }^{169}$ Id.

${ }^{160} I d$.

161 See id.

162 Id. § 2A-209(1).

$16 \mathrm{See}$ id. $\S 2 \mathrm{~A}-209$ official comment.

164 Id. 
under the supply contract on the lessee."165

Subsection (3) protects the lessee from modification or rescission of the supply contract by the supplier and the lessor. If the supplier has notice of the finance lease, the change will be ineffective against the lessee. ${ }^{168}$ In addition, the lessee has a cause of action against the lessor if the modification or rescission occurs after the lessee entered into the lease; in that case, if the supplier also had notice of the lease, the lessee will have a cause of action against it as well. ${ }^{167}$

Section $2 A-407^{168}$ presents the finance lessee with the flip side of the coin by making the lessee's promises under the lease irrevocable and independent upon its acceptance of the goods. The purpose of this "hell or high water" provision is indicated by the specific reference in clause (2)(a) to "assignees of the parties." The official comment explicitly states that this section "requires the lessee to perform even if the lessor's performance after the lessee's acceptance is not in accordance with the lease contract." the benefit of the supplier's promises and warranties to the lessor under the supply contract is extended to the lessee under the finance lease."170

These rights that Article 2A confers on true finance lessors, however, are more powerful than those that Article 9 gives to security interest lessors. Section 9-206(1) provides that buyers or (security interest) lessees may make agreements not to assert defenses against assignees, and that such agreements are enforceable by assignees who take the assignment "for value, in good faith and without notice of a claim or defense."171 Note that, unlike section 2A-407, this provision is permis-

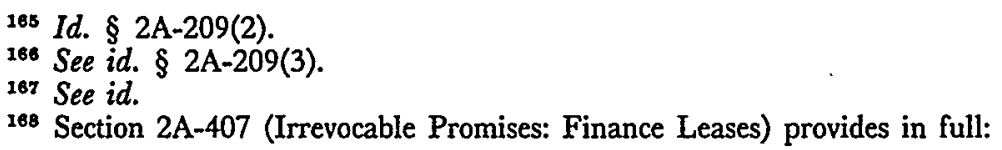

(1) In the case of a finance lease that is not a consumer lease the lessee's promises under the lease contract become irrevocable and independent upon the lessee's acceptance of the goods.

(2) A promise that has become irrevocable and independent under subsection (1):

(a) is effective and enforceable between the parties, and by or against third parties including assignees of the parties, and

(b) is not subject to cancellation, termination, modification, repudiation, excuse, or substitution without the consent of the parties to whom the promise runs.

Id. $\S 2 \mathrm{~A}-407$.

${ }_{169}$ Id. $\S 2 \mathrm{~A}-407$ official comment (emphasis added).

$170 I d$.

${ }_{171}$ Id. § 9-206(1); see also Equico Lessors, Inc. v. Rockville Reminder, Inc., 492 A.2d 528, 530 (1985) (ruling that the assignee of a lease could not enforce the waiver of defenses provision of $\S 9-206(1)$ because it had not taken the assignment without notice of a claim or defense); Chemical Bank v. Rinden Professional Ass'n, 126 N.H. 
sive, so that the lessee may choose not to make such an agreement. Further, note that, except for the obligation of good faith, ${ }^{172}$ the assignee of a true finance lessor, under Article $2 \mathrm{~A}$, need not meet the other requirements in order to be free from claims and defenses. ${ }^{173}$ These two differences translate into a benefit conferred on the assignor, because it will obtain a more valuable right to sell. There would seem to be no principled basis for giving this valuable advantage to true finance lessors, but not to security interest finance lessors.

The harshness of section 2A-407 is mitigated by its being "subject to . . . the lessee's revocation of acceptance."174 Because the lessee's right to revoke against a finance lessor is very limited, ${ }^{175}$ however, this concession is of limited benefit to the lessee.

\section{Warranties}

In keeping with the policy that a finance lessee should look almost exclusively to the supplier for representations, covenants, and warran-

$688,692-95,498$ A.2d 706, 711-12 (1985) (finding a waiver of defenses clause to be valid under $\S 9-206(1)$ when the assignee of a lease had taken the assignment for value, in good faith, and without notice of a claim or defense). full:

Section 9-206(1) (Agreement Not to Assert Defenses Against Assignee) provides in

Subject to any statute or decision which establishes a different rule for buyers or lessees of consumer goods, an agreement by the buyer or lessee that he will not assert against an assignee any claim or defense which he may have against the seller or lessor is enforceable by an assignee who takes his assignment for value, in good faith and without notice of a claim or defense, except as to defenses of a type which may be asserted against a holder in due course of a negotiable instrument under the Article on Commercial Paper (Article 3). A buyer who as part of one transaction signs both a negotiable instrument and a security agreement makes such an agreement.

U.C.C. § 9-206(1). The official comment explains that this provision follows the law of negotiable instruments, and it is apparent that an assignee allowed to enforce such an agreement must meet requirements similar to those met by a holder in due course. See id. § 9-206(1) official comment; cf. id. § 3-302(1) ("A holder in due course is a holder who takes the instrument (a) for value; and (b) in good faith; and (c) without notice that it is overdue or has been dishonored or of any defense against or claim to it on the part of any person."). Interestingly, the official comment to $\S 9-206$ states that "[ $t]$ he same rules are made applicable to leases as to security agreements, whether or not the lease is intended as security." Id. § 9-206(1) official comment (emphasis added). One wonders why the drafters, in creating $\$ 2 \mathrm{~A}-407$ and thereby supplanting the official comment, abandoned this consistent treatment for all leases. For a case that applied § 9-206(1) without inquiring into the nature of the lease, see Equico Lessors, 492 A.2d at 530.

172 See U.C.C. $\S \S 1-203,2 A-103(4)$.

173 See id. $\S 2 A-407(2)(a)$.

${ }^{174}$ Id. $\S 2 \mathrm{~A}-407$ official comment.

175 See supra notes $92-102$ and accompanying text. 
ties, the provisions on the creation of warranties restrict a finance lessor to responsibility only for express warranties and warranties against interference. ${ }^{176}$ For express warranties, "[a]ny affirmation of fact or promise made by the lessor to the lessee which relates to the goods and becomes part of the basis of the bargain creates an express warranty that the goods will conform to the affirmation or promise."177 With respect to the warranty against interference, in each lease contract there is a "warranty that for the lease term no person holds a claim to or interest in the goods that arose from an act or omission of the lessor, other than a claim by way of infringement or the like, which will interfere with the lessee's enjoyment of its leasehold interest." ${ }^{\text {"178 }}$ Both provisions require very little of the finance lessor if the proper precautions are taken. ${ }^{179}$

\section{Risk of Loss}

The risk-of-loss provisions in Article $2 \mathrm{~A}^{180}$ also reflect the general scheme identified above. In a lease, the risk of loss is generally placed on the lessor, but in a finance lease it passes to the lessee. ${ }^{181}$ When, however, goods identified to a lease contract suffer a total loss before the risk of loss passes to the lessee, then the contract is "avoided" and both parties bear their own losses. ${ }^{182}$ These rules are modified by the effects of rejection and revocation. ${ }^{183}$ When the condition of the goods confers on the finance lessee the right to reject, the risk of loss is on the supplier until cure or acceptance. ${ }^{184}$ If the lessee rightfully revokes ac-

178 "Except in a finance lease," a lease contract may imply a warranty of merchantability or a warranty of fitness for a particular purpose. U.C.C. $\S \S 2 A-212$, 2A-213.

177 Id. § $2 \mathrm{~A}-210(1)(\mathrm{a})$.

${ }^{178} I d$. $\S 2 \mathrm{~A}-211(1)$.

179 See supra notes $122-47$ and accompanying text.

180 See U.C.C. $\$ \S 2 A-219$ to -221 .

181 See id. \& 2A-219(1).

182 See id. § 2A-221(a).

${ }^{183}$ Section 2A-220(1) provides:

Where risk of loss is to pass to the lessee and the time of passage is not stated:

(a) If a tender or delivery of goods so fails to conform to the lease contract as to give a right of rejection, the risk of their loss remains with the lessor, or, in the case or a finance lease, the supplier, until cure or acceptance.

(b) If the lessee rightfully revokes acceptance, he [or she], to the extent of any deficiency in his [or her] effective insurance coverage, may treat the risk of loss as having remained with the lessor from the beginning.

Id. $\S 2 \mathrm{~A}-220(1)$.

${ }_{184}$ See id. § $2 \mathrm{~A}-220(1)(\mathrm{a})$. 
ceptance, then, to the extent that there is a deficiency in the lessee's insurance coverage, the risk of loss is borne by the lessor. ${ }^{185}$

Although adequate insurance would make these provisions unnecessary, recognizing that the risk of loss is tied in some sense to ultimate responsibility for or ownership of the goods reveals an interesting pattern. When the lessee would have the right to reject, Article $2 \mathrm{~A}$ imposes ultimate responsibility for the goods on the supplier. ${ }^{186}$ In contrast, when the lessee revokes acceptance, the lessor bears the ultimate responsibility. ${ }^{187}$ Thus, it seems that in a true finance lease rejection is a remedy to be had ultimately against the supplier, while revocation works against the lessor.

\section{Acceptance, Rejection, and Revocation}

The acceptance, rejection, and revocation provisions in Article 2A all seem to bear out the observation that rejection redounds to the supplier, while revocation primarily affects the finance lessor; nevertheless, some confusion remains. Under section 2A-515(1), a finance lessee accepts goods if, after a reasonable opportunity to inspect, it "signifies or acts with respect to the goods in a manner that signifies to the lessor or the supplier that the goods are conforming or that [it] will take or retain them." ${ }^{188}$ In order to reject goods not conforming to the lease contract, however, the lessee must seasonably notify the lessor. ${ }^{189}$ Yet either the lessor or the supplier may attempt a cure. ${ }^{100}$

Similarly, failure of the lessee seasonably to state objections effects a waiver of the objections if the lessor or the supplier could have cured the defect. ${ }^{191}$ Furthermore, a lessee's duties with respect to rightfully rejected goods lie with both the lessor and the supplier. ${ }^{192}$ The lessee may, however, revoke acceptance "without discovery of the nonconformity if the lessee's acceptance was reasonably induced . . . by the lessor's assurances."193

The official comment to section 2A-516 clarifies some of this ap-

185 See id. § 2A-220(1)(b).

${ }^{188}$ See id. § 2A-220(1)(a).

${ }^{187}$ See id. § 2A-220(1)(b).

${ }^{188} I d$. $\S 2 \mathrm{~A}-515(1)(\mathrm{a})$ (emphasis added).

${ }^{180}$ See id. § 2A-509(2).

190 See id. \& 2A-513(1).

192 See id. § 2A-514(1)(a).

192 See id. § 2A-511 (merchant lessee's duties); id. § 2A-512 (non-merchant lessee's duties).

${ }^{103}$ Id. $\S 2 \mathrm{~A}-517(1)(\mathrm{b})$ (emphasis added). 
parent confusion:

Subsection (2) creates a special rule for finance leases, precluding revocation if acceptance is made with knowledge of nonconformity with respect to the lease agreement, as opposed to the supply agreement; this is not inequitable as the lessee has a direct claim against the supplier. Section 2A209(1). Revocation of acceptance of a finance lease is permitted if the lessee's acceptance was without discovery of the nonconformity (with respect to the lease agreement, not the supply agreement) and was reasonably induced by the lessor's assurances. Section 2A-517(1)(b). Absent exclusion or modification, the lessor under a finance lease makes certain warranties to the lessee. Sections 2A-210 and 2A-211(1). Revocation of acceptance is not prohibited even after the lessee's promise has become irrevocable and independent. Section 2A-407 official comment. Where the finance lease creates a security interest, the rule may be to the contrary. ${ }^{194}$

Although section 2A-516(2) makes no specific reference to "nonconformity with respect to the lease agreement," the official comment may not represent an unwarranted interpretation of the term "conforming." Its reading is supported by the definition of "conforming," which refers only to goods or performance that conform "under a lease contract."195 Because Article 2A deals only with leases, we must infer that, where the term "nonconformity" appears, it actually means "nonconformity with respect to the lease contract." Therefore, there are two separate issues of conformity in a finance lease: conformity with the lease contract and conformity with the supply contract. The finance lessee's rights with respect to nonconformity in the supply contract are derived from the supply contract itself, as made applicable to the lessee by the operation of the redirection provisions. ${ }^{196}$ Therefore, if the supply contract is a sales contract, then acceptance, rejection, and revocation of acceptance by the lessee are governed by Article 2 . If the supply contract is itself a lease contract, then it, as well as the lease between the finance lessor and the finance lessee, is governed by Article 2A. Assuming for the sake of simplicity that in the latter case the supply contract is not itself a finance lease, the rights of the finance lessee to reject or revoke acceptance of the supply contract will be similar

${ }^{194}$ Id. $\S 2 \mathrm{~A}-516$ official comment (emphases added) (citing General Elec. Credit Corp. v. Ger-Beck Mach. Co., 806 F.2d 1207 (1986)).

193 Id. $\S 2 \mathrm{~A}-103(1)(\mathrm{d})$.

${ }^{206}$ See id. § 2A-209; supra notes $162-67$ and accompanying text. 
whether the supply contract is a sales contract or a lease. ${ }^{197}$

Given that rejection or revocation of the supply contract is distinct from rejection or revocation of the finance lease contract, the remaining confusion can be attributed to a reasonable, albeit unstated, assumption in the finance lease provisions of Article $2 \mathrm{~A}$. The assumption is that, when goods or performance conform to the supply contract, they will conform to the lease contract, and when they do not conform to the lease contract, they will not conform to the supply contract. This assumption follows from an underlying assumption that a finance lessor will generally promise less, and certainly not more, than the supplier with regard to the goods or their tender or delivery. This is in keeping with the view of the finance lessor as basically a conduit for the goods. ${ }^{198}$ When a lessee rightfully rejects goods on account of a nonconformity with respect to the lease contract, the lessor itself ${ }^{\mathbf{1 9 9}}$ may exercise rejection against the supplier on the ground that the goods did not conform to the supply contract. By the same token, when the lessee meets all of the requirements of a justifiable revocation against the lessor, the lessor may turn around and revoke against the supplier. If the lessee accepts, there are no problems. Therefore, if the goods or their tender or delivery do not conform to the supply contract, but do conform to the lease contract, such as when there are no representations at all by the lessor, then the lessee may reject or revoke acceptance of the goods and cancel the supply contract, ${ }^{200}$ but the lessor and lessee would still have a valid lease contract. In such a case, the lease contract would probably provide for another tender by the supplier, substitution of another supplier, or liquidated damages or the acceleration of rents. ${ }^{201}$

Given the underlying assumption, the apparent inconsistencies in the acceptance, rejection, and revocation provisions are reconcilable. Because conformity with the supply contract implies conformity with the lease contract, acceptance of the lease contract may be signified to either the lessor or the supplier. ${ }^{202}$ For the same reason, either the lessor or the supplier may attempt a cure to effect conformity. ${ }^{203}$ Similarly, the

${ }^{197}$ See supra notes $77 \& 92-97$ and accompanying text. Compare U.C.C. § 2-601 (giving buyers the right to reject) with $i d . \S 2 A-509$ (giving lessees the right to reject); id. $\S 2-608$ (giving buyers the right to revoke) with id. $\S 2 \mathrm{~A}-517$ (giving lessees the right to revoke).

${ }^{298}$ See U.C.C. $\S 2 A-103(1)$ (g) official comment.

199 Section 2A-209, which extends the benefits of the supply contract to the lessee, does not take them away from the lessor. See id. $\S 2$ A-209.

${ }^{200}$ See supra notes 105-10 and accompanying text.

201 See U.C.C. $\S 2 \mathrm{~A}-504$ (Liquidation of Damages); id. $\S 2 \mathrm{~A}-529$ (Lessor's Action for the Rent).

${ }_{202}$ See id. $\S 2 A-515(1)(a)$.

203 See id. $\$ 2 \mathrm{~A}-513$. 
lessee waives its objections if it does not seasonably state them and either the lessor or the supplier could have cured the defect. ${ }^{204}$ On the other hand, because nonconformity with the supply contract does not imply nonconformity with the lease contract, if the lessee wishes to reject the lease contract, it must notify the lessor, not the supplier. ${ }^{205}$ Conversely, because nonconformity with the lease contract implies nonconformity with the supply contract, the lessor will be able to reject against the supplier if the lessee rejects against the lessor. ${ }^{206}$ Hence, the lessee's duties regarding rightfully rejected goods run to the lessor as well as the supplier in order to preserve the lessor's right to reject. ${ }^{207}$ Finally, because revocation is against the lessor, the lessee must be induced by the lessor's assurances, ${ }^{208}$ not the supplier's, and it must notify the lessor, ${ }^{200}$ not the supplier.

Although it reconciles and explains the effects of the provisions, this assumption is not applicable in all circumstances. It fails if the lessor makes a representation in the lease contract with respect to the goods that was not made by the supplier in the supply contract. This might occur if the lessor turns out not to have acquired from the supplier good title to the goods. ${ }^{210}$ It also fails if the lessor is found to have a duty under the lease contract with respect to the goods or their tender or delivery, ${ }^{211}$ such as not to interfere with the right of the lessee to reject or revoke against the supplier. ${ }^{212}$ Article $2 \mathrm{~A}$ contemplates both of these possibilities ${ }^{213}$ without, however, contemplating the consequences of such obligations. In such situations, if the goods do not conform to the lessor's representation, or if the lessor does not discharge its duty, then the lessee could reject or revoke acceptance of the lease contract, although it may not be able to do so with respect to the supply contract.

204 See id. \& 2A-514.

205 Id. $\S 2 \AA-509(2)$.

${ }^{206}$ See supra note 199 and accompanying text.

${ }^{207}$ See U.C.C. § $2 A-511$ (concerning merchant lessees' duties with respect to rightfully rejected goods); $i d$. $\S 2 \mathrm{~A}-512$ (concerning nonmerchant lessees' duties with respect to rightfully rejected goods).

208 See id. § 2A-517(1)(b).

${ }^{209}$ See id. § 2A-517(2).

210 This may result in a breach of the lessor's express warranties to the lessee or its warranty against interference; alternatively, it may result in a failure of consideration. See supra notes 133-47 \& 176-79 and accompanying text.

${ }^{211}$ In Tri-Continental Leasing Corp. v. Law Office of Richard W. Burns, 710 S.W.2d 604 (Tex. Ct. App. 1985), the finance lessor was found to have impliedly authorized the supplier's salesman to act and make representations on its behalf, and so the lessee was allowed to "rescind" the lease of a defective copier. See id. at 607.

${ }^{212}$ See supra notes 133-47 \& 176-79 and accompanying text.

213 See U.C.C. § 2A-211(1) (giving lessees a warranty against lessors' interference); id. $\S 2 \mathrm{~A}-103(1)(\mathrm{g})$ official comment ("[T]his definition [of 'finance lease'] does not restrict the lessor's function solely to the supply of funds ....."). 
The effect of such a rejection or revocation would be to cancel the lease contract. If the goods conform to the supply contract, however, the lessor would not be able to reject or revoke in turn against the supplier. Thus, the lessor could be stuck with the goods and no lease.

This should be, and does appear to be, the working of the acceptance, rejection, and revocation provisions. If, however, it is true that conformity to the supply contract is entirely independent of conformity to the lease contract, then one major inconsistency remains in the provisions. Because goods may conform to the supply contract, yet not conform to the lease contract, signifying to the supplier that the goods are conforming should, for two reasons, not be relevant to acceptance with respect to the lease contract. ${ }^{214}$ First, the supplier is unlikely to know of the precise obligations in the lease contract. Second, even if the lessee happens to signify directly to the supplier that the goods are conforming to the lease contract, there is still the question why, in the absence of any agency or the like, that act should confer rights on the lessor, a third party. Therefore, the reference to the supplier should either be deleted from section 2A-515(1)(a) or appropriately qualified.

Given the above, why is revocation by the finance lessee more limited against the finance lessor than against the supplier?216 Once again, the answer lies in the implicit assumption pervading Article $2 \mathrm{~A}$ that the finance lessor's function is limited to serving as a financing party for the lessee so that the lessee may obtain the desired goods. In the context of a financing transaction, the financing party is likely to know even less than the supplier about the business of the lessee, the usage of that trade, and the condition of the goods when delivered. Therefore, the reasons for making revocation more difficult to invoke than rejection when used against the supplier are even more applicable to revocation against the finance lessor. ${ }^{216}$

If the financing party's role is so limited, however, one might ask why the finance lessee has any right of revocation, or even rejection, against the lessor. The answer to this question is that, by entering into a lease, the lessor undertakes to perform on certain promises and makes certain warranties. To the extent that it cannot perform adequately, the lessee should be entitled to some remedy. Rejection or revocation is not an inappropriate remedy if one recognizes the distinction between rejection or revocation against, on one hand, the finance lessor, and, on the

214 See id. § 2A-515(1)(a).

216 In a finance lease, a lessee may revoke only if it was reasonably induced by the lessor's assurances to accept before it had discovered the nonconformity. See supra notes 98-100 and accompanying text.

${ }^{216}$ See supra notes $114-16$ and accompanying text. 
other hand, the supplier. Rejection or revocation against the finance lessor affects only the continuing validity of the lease contract. The conditions necessary for rejection or revocation depend only on the finance lessor's performance, not the supplier's. From the finance lessor's point of view, it should not be affected economically by whether performance by the supplier is conforming or not. If the lessee rejects or revokes against the supplier, the finance lessor should still be entitled to the benefit of its bargain by the lessee either substituting a supplier or paying some sort of damages. Conversely, if the lessor fails to perform adequately and the lessee rejects or revokes the lease contract, the supply contract between the lessor and the supplier should remain valid. In the typical case in which a nonconformity with respect to the lease contract implicates a nonconformity with respect to the supply contract, the finance lessor is protected by being able to reject or revoke against the supplier should the lessee reject or revoke the lease contract.

The official comment to section 2A-517 states that, although the section was based on the analogous section $2-608$, the rule was "[r]evised to reflect leasing practices." The framework adopted by Article $2 \mathrm{~A}$ for finance leases follows the scheme commonly adopted by the parties.

\section{B. The Security Interest Finance Lease}

Although Article 2A provides explicit and rather comprehensive treatment of true finance leases, the Code does not provide a corresponding treatment for security interest finance leases. ${ }^{218}$ Nonetheless, the necessary building blocks are present: transfer of the benefit of the supply contract, irrevocability of the lessee's promises, applicability of warranties, and risk of loss rules. The transfer of the benefit of the supply contract in the case of security interest finance leases has been developed in the case law. Courts have generally held that warranties and representations provided by the supplier to the buyer can be asserted by the finance lessee. ${ }^{218}$ By the same token, most of the buyer's remedies against the supplier are also available to the finance lessee. ${ }^{220}$ Irrevocability of the finance lessee's promises is dealt with in section 9-

212 U.C.C. § $2 A-517$ official comment.

${ }^{218}$ See id. $\$ 2 A-103(1)(\mathrm{g})$ (defining "finance lease" as a form of true lease); supra notes 149-50 and accompanying text (noting that finance leases are leases).

${ }^{219}$ See Harris, Recent Cases Relating to Equipment Leases, in BAsICs of EQUIPMENT LEASING 1987, supra note 2, at 177, 209-12; Reisman \& Mooney, supra note 2, at 53-54.

220 See Harris, supra note 219, at 215-29. 
$206(1) ; 2$ risk of loss in breach is provided for in section 2-510; and casualty to identified goods is treated in section 2-613.

As framed by the courts, the main Article 2 issue is whether the supplier or the finance lessor is to be considered the seller under the specific circumstances surrounding the lease. In General Electric Credit Corp. v. Ger-Beck Machine Co. (GECC), ${ }^{222}$ the only case to consider this question generally within the context of revocation of acceptance against the finance lessor, the answer given by a divided Court of Appeals was that the seller was the supplier. ${ }^{223}$ The court found that the finance lessor provided nothing in the three-way transaction except the money to finance a sale between the supplier and the finance lessee. ${ }^{224}$ It concluded as a matter of law that the transaction between the finance lessor and the finance lessee was only a security transaction. ${ }^{225}$ Hence, it ruled that the transaction was outside the scope of Article 2 and denied revocation to the lessee. ${ }^{226}$ In so reasoning, it relied on a state court case, from the state where the court sat, that had denied a finance lessee a remedy against the finance lessor for breach of the implied warranty of merchantability. ${ }^{227}$

The dissenting judge did not agree that the finance lessor was merely a financing party. ${ }^{228} \mathrm{He}$ noted that the finance lessor used its own standard forms so that it could inject itself into the chain of title and that the lease specified that "the Equipment shall be at all times the personal property of Lessor." $229 \mathrm{He}$ considered the warranty of merchantability case cited by the court not to be on point, because the revocation of acceptance is very different from implied warranties. ${ }^{230}$

221 See id. at 230-33 (discussing case law); supra note 171 (discussing $§ 9-206(1)$ and case law).

${ }^{222} 806$ F.2d 1207 (3d Cir. 1986) (2-1 decision).

${ }^{223}$ See id. at 1209-10. But of. Freeman v. Hubco Leasing, Inc., $253 \mathrm{Ga}$. 698, 706, 324 S.E.2d 462, 470 (1985) (ruling that a finance lessee could revoke acceptance against a finance lessor when the finance lessor and supplier had the same stockholders, directors, and officers, but not considering whether the lease was a true lease or a security interest lease); Tri-Continental Leasing Corp. v. Law Office of Richard W. Burns, 710 S.W.2d 604, 606 (Tex. Ct. App. 1985) (2-1 decision) (ruling that a finance lessee was allowed to "rescind" against a finance lessor for failure of consideration, although not considering whether the lease was a true lease or a security interest lease).

224 See GECC, 806 F.2d at 1211.

225 See id.

228 See id. at $1208,1211$.

${ }^{227}$ See id. at 1209-11 (quoting Miller Auto Leasing Co. v. Weinstein, 189 N.J. Super. 543, 461 A.2d 174 (Law Div. 1983), affd, 193 N.J. Super. 328, 473 A.2d 996 (App. Div. 1984), cert. denied, 97 N.J. 676, 483 A.2d 192 (1984)).

${ }^{228}$ See id. at 1211 (dissenting opinion).

228 Id. at 1212 (dissenting opinion).

230 See id. at 1214-17 (dissenting opinion) (criticizing the majority's reading of Miller Auto Leasing). 
The judge referred to the concerns behind the operation of acceptance and the "perfect tender rule"231 and explained that the different concerns presented by the revocation of acceptance support its being applied more widely than implied warranties. ${ }^{232}$ By way of support, he relied on an assignment of lease case, ${ }^{233}$ similar to transaction $C,{ }^{234}$ for the proposition that a transaction with both sales and security aspects is within the scope of Article 2. Because in GECC the finance lessor had acquired title to the goods, it was effectively the seller to the finance lessee. ${ }^{235}$ Therefore, stated the dissent, the finance lessee could revoke acceptance against the finance lessor.

The dissent did not, however, consider whether revocation against the finance lessor might require different standards compared with revocation against the supplier. Although the goods did not conform to the supplier's representations, ${ }^{236}$ there is no suggestion that the lessor undertook to make similar representations on its part. In all likelihood, then, the defects in the goods did not implicate nonconformity with the lease contract. Hence, revocation of the lease should not have been justified. Even if the goods were not in conformity with the lease contract because of the defects, however, the lessor in this case had not seen the goods or known of the defects. ${ }^{237}$ Acceptance had been induced by the assurances of the supplier, ${ }^{238}$ but not of the lessor, and perhaps also by the lessee's reasonable assumption that the nonconformity would be cured by the supplier. If Article 2A's scheme were to apply, revocation against the finance lessor would be unjustified. ${ }^{238}$

The dissenting judge concluded by pointedly observing that the real question presented by the case concerned the allocation of risk and potential litigation expenses. ${ }^{240}$ Under normal circumstances, his approach would allow the finance lessor to revoke in its turn against the supplier; in this instance, however, the supplier was in "financial difficulty." "241 The lease contract could have allocated the risk explicitly, but the issue of revocation was overlooked. Because the finance lessor was

${ }^{231}$ See supra notes 77-85 and accompanying text.

${ }^{232}$ See GECC, 806 F.2d at 1216 (dissenting opinion).

23s See id. at 1213 (dissenting opinion) (citing Associates Discount Corp. v. Palmer, 47 N.J. 183, 219 A.2d 858 (1966)).

${ }^{234}$ See supra note 55 and accompanying text.

235 See GECC, 806 F.2d at 1217 (dissenting opinion).

${ }^{238}$ See id. at 1208.

${ }^{237}$ See id. (describing how, although defects appeared in the lathe from the beginning, the lessor was not notified of the problems for two years while the supplier attempted to correct them).

238 See id. at 1208.

239 See U.C.C. §§ 2A-516(2), 2A-517(1).

${ }^{240}$ See GECC, 806 F.2d at 1217 (dissenting opinion).

241 See id. (dissenting opinion). 
quite sophisticated, had considerable leverage, and had used its own standard form, the contract could be read against the drafter. ${ }^{242}$ All of these factors led the dissent to view as a question of fact whether the finance lessor had done enough to make it a seller in this context, a question that the jury had answered in the affirmative.

\section{Reconciliation}

The Code's general provisions support a reading that follows the commercial practice, yet allows for variation by agreement of the parties. First, "any usage of trade in the vocation or trade in which [the parties] are engaged or of which they are or should be aware give[s] particular meaning to and supplement[s] or qualif[ies] terms of an agreement."243 Second, the UGC is to be "liberally construed and applied to promote its underlying purposes and policies," 244 among which are "to simplify, clarify and modernize the law governing commercial transactions" 245 and "to permit the continued expansion of commercial practices through custom, usage and agreement of the parties."248 Third, "[ $\mathrm{t}]$ he effect of [the] provisions of this Act may be varied by agreement,"247 whether or not the words "unless otherwise agreed" appear in any particular provision. ${ }^{248}$ Finally, parties are accountable for their bargaining: "The remedies provided by this Act shall be liberally administered to the end that the aggrieved party may be put in as good a position as if the other party had fully performed." 249 By implication, if the other party has fully performed, then the first party can have no complaint against it and, consequently, no remedy is necessary.

In accordance with these provisions, the rule with respect to acceptance, rejection, and revocation of acceptance should be the same in the case of any finance lease, whether it is a true lease or one intended as security. The concerns in both instances are the same. Because Article $2 \mathrm{~A}$ addresses substantially all of those concerns, while Articles 2 and 9 do not, the rule should substantially follow the provisions set forth in Article 2A. To properly allocate the risks and costs of rejection

242 See id. (dissenting opinion).

${ }^{243}$ U.C.C. $\S 1-205(3)$. Under $\S 1-205(2)$, "[a] usage of trade is any practice or method of dealing having such regularity of observance in a place, vocation or trade as to justify an expectation that it will be observed with respect to the transaction in question."

${ }^{244} I d . \S 1-102(1)$.

${ }^{245} I d$. $\S 1-102(2)(\mathrm{a})$.

${ }^{246} I d$. $\S 1-102(2)(\mathrm{b})$.

${ }^{247}$ Id. \& 1-102(3).

${ }^{248} I d$. \& 1-102(4).

240 Id. § $1-106$. 
and revocation between the parties, conformity to a lease contract should be distinct from conformity to the supply contract. Neither the finance lessor nor the supplier should be held accountable for the nonconformity of the other's performance. Each party's own performance should be the measure of the remedy for the finance lessee. This approach is fair, because the parties get the benefit of their separate bargains, and no one is obliged to be the insurer of another without having so undertaken. In this regard, both the majority and the dissenting opinions in GECC can be reconciled with this position, because they turned on facts that were open to differing interpretations. It is essential, however, that the parties be able, by agreement, to modify the effect of the rules in order to vary the allocation of the risks and costs. In addition, in order to avoid surprises and simplify the drafting of agreements, the "default setting" should be based on the predominant finance lease practice. Such a scheme accords with the underlying purposes and policies of the Code.

\section{CONCLUSION}

Revocation of acceptance is a remedy that is integral to the scheme presented by the Uniform Commercial Code to deal with acceptance and rejection of goods. However, its operation in the context of the finance lease, a common and economically important transaction, needs further review. Although the newly promulgated Article $2 \mathrm{~A}$ on leases provides a reasoned approach to finance leases that are true leases, there is conflicting case law for finance leases that are security interest leases. The underlying functions and motivations of both types of finance lease are the same. Consequently, a unified treatment should be given to both types of finance lease. This Comment proposes that Article $2 \mathrm{~A}$ 's approach, read in the proper light, is sufficiently coherent and flexible to be adopted in the context of the security interest finance lease. 


$$
\text { - }
$$

